\title{
Key Proteins of Activating Cell Death Can Be Predicted through a Kainic Acid-Induced Excitotoxic Stress
}

\author{
Hsiu-Ling Tsai ${ }^{1}$ and Sue-Joan Chang ${ }^{2}$ \\ ${ }^{1}$ Department of Food Nutrition, Chung Hwa University of Medical Technology, Jente, No. 89, Wunhua 1st Street, \\ Rende District, Tainan City 717, Taiwan \\ ${ }^{2}$ Department of Life Sciences, National Cheng Kung University, Tainan 701, Taiwan
}

Correspondence should be addressed to Hsiu-Ling Tsai; tsai007007@yahoo.com.tw

Received 4 August 2014; Revised 16 October 2014; Accepted 17 October 2014

Academic Editor: Antoni Camins

Copyright (C) 2015 H.-L. Tsai and S.-J. Chang. This is an open access article distributed under the Creative Commons Attribution License, which permits unrestricted use, distribution, and reproduction in any medium, provided the original work is properly cited.

Epilepsy is a major neurological disorder characterized by spontaneous seizures accompanied by neurophysiological changes. Repeated seizures can damage the brain as neuronal death occurs. A better understanding of the mechanisms of brain cell death could facilitate the discovery of novel treatments for neurological disorders such as epilepsy. In this study, a model of kainic acid- (KA-) induced neuronal death was established to investigate the early protein markers associated with apoptotic cell death due to excitotoxic damage in the rat cortex. The results indicated that KA induces both apoptotic and necrotic cell death in the cortex. Incubation with high concentrations (5 and $500 \mu \mathrm{M},>75 \%)$ and low concentrations $(0.5 \mathrm{pM}$ : $95 \%$ and $50 \mathrm{nM}$ : $8 \%$ ) of KA for $180 \mathrm{~min}$ led to necrotic and apoptotic cell death, respectively. Moreover, proteomic analysis using twodimensional gel electrophoresis and mass spectrometry demonstrated that antiapoptotic proteins, including heat shock protein 70, 3-mercaptopyruvate sulfurtransferase, tubulin-B-5, and pyruvate dehydrogenase E1 component subunit beta, were significantly higher in apoptosis than in necrosis induced by KA. Our findings provide direct evidence that several proteins are associated with apoptotic and necrotic cell death in excitotoxicity model. The results indicate that these proteins can be apoptotic biomarkers from the early stages of cell death.

\section{Introduction}

Epilepsy is a major neurological disorder characterized by spontaneous seizures (discharges) accompanied by motor and/or perceptual dysfunction. Recently, researchers have proposed that the underlying pathological mechanisms of epilepsy are excessive activation of excitatory amino acid (EAA) receptors, with accompanying generation of reactive oxygen species (ROS) $[1,2]$. Studies have demonstrated the relationship between oxidative stress and epileptic seizures in animal models, with markedly increased mitochondrial superoxide production and intracellular $\mathrm{Ca}^{2+}$ concentration $\left(\left[\mathrm{Ca}^{2+}\right]_{\mathrm{i}}\right)[3]$, or mitochondrial dysfunction [4]. A growing number of in vivo and in vitro studies have also confirmed that oxidative stress induces cell death in excitotoxic injury $[5,6]$.

Several experimental models of epileptic seizures have been developed using EAA receptor agonists such as lithium-pilocarpine or kainic acid (KA). KA is an agonist of the $\alpha$-amino-3-hydroxy-5-methyl-4-isoxazolepropionic acid (AMPA) subtype of EAA receptors and is widely used to study the mechanisms behind neurological disorders by creating models of cell damage. KA has been reported to induce excitotoxic cell death in immature and adult animals by systemic or intraventricular injection and in primary cultures and in vitro neuronal cell lines $[7,8]$. Two types of neuronal death, including apoptosis and necrosis, have been proposed to occur in the KA models. A number of studies have reported that apoptosis was the major mode of cell death, while a few studies have suggested the existence of KA-induced necrotic cell death, as well as the coexistence of apoptosis and necrosis in the brain $[9,10]$.

Apoptosis and necrosis are two main types of cell death both with distinct morphological and molecular features. Apoptosis is described as an active, well-regulated, and energy-dependent form of cell death. In contrast, necrosis 
represents a passive, less orderly, non-energy-requiring form. In the past two decades many studies have reported the toxic events ultimately leading to cell death through disturbed homeostasis, such as excess ROS production [11], ATPgeneration blocking [12], or activation of death receptors (such as the Fas/CD95/Apol receptor [13], TNF receptor [14], or the NMDA receptor [15]). The main proteins involved in determining the mode of cell death, be it by apoptosis or necrosis, remain unclear. The present study aimed to provide direct evidence for the involvement of different proteins in the two modes of neuronal death. The study was designed to identify and compare protein expression patterns in apoptosis and necrosis of cortical cells through an excitotoxicity-induced neuronal cell death model.

\section{Materials and Methods}

2.1. Isolation of Dissociated Immature Cortical Cells. Dissociated immature cortical cells from 14-day-old Sprague-Dawley rats (purchased from the Animal Center of the Medical College, National Cheng Kung University, Tainan, Taiwan) were prepared by collagenase $\mathrm{A}(0.33 \mathrm{mg} / \mathrm{mL})$ digestion at $37^{\circ} \mathrm{C}$ for $30 \mathrm{~min}$ in a shaking bath. After washing with Eagle's minimal essential medium (MEM, GIBCO), the cells were cultured in MEM with $10 \%$ fetal bovine serum and maintained for $24 \mathrm{~h}$ at $37^{\circ} \mathrm{C}$ in an atmosphere of $95 \%$ air and $5 \% \mathrm{CO}_{2}$. The density of the dissociated immature cortical cells (mixed neuronal and glial cells) was adjusted to $10^{6}$ cells $/ \mathrm{mL}$ for KA induction.

2.2. Kainic Acid (KA) Induction. KA (Sigma) was prepared as a concentrated stock solution $(1 \mathrm{mM})$ in the cell culture medium. Dissociated immature cortical cells were treated with $\mathrm{KA}$ at the concentrations of $0.005 \mathrm{pM}$ to $500 \mu \mathrm{M}$ $(0.005 \mathrm{pM}, 0.5 \mathrm{pM}, 50 \mathrm{nM}, 5 \mu \mathrm{M}$, and $500 \mu \mathrm{M})$ for 5,30 , 60 , and $180 \mathrm{~min}$ at $37^{\circ} \mathrm{C}$ in a shaking water bath, under an atmosphere of $95 \% \mathrm{O}_{2} / 5 \% \mathrm{CO}_{2}$. Each concentration and duration of application was analyzed in triplicate. The methods used to characterize the cellular responses of cortical cells to excitotoxic insults induced by KA are described below.

\subsection{Flow Cytometric Measurement of Intracellular Oxidative} Stress in Immature Cortical Cells after KA Induction. Flow cytometric analysis was undertaken to investigate KA excitatory neurotoxicity and its relationship to quantitative changes in ROS, $\left[\mathrm{Ca}^{2+}\right]_{\mathrm{i}}$, and mitochondrial membrane potential (MMP). Briefly, $1 \mathrm{~mL}$ of dissociated immature cortical cells $\left(10^{6}\right.$ cells $)$ treated with $\mathrm{KA}$ at five different concentrations for four different induction times as mentioned above was incubated with fluorescent dye. ROS generation was measured using $2^{\prime}, 7^{\prime}$-dichlorofluorescein diacetate (DCFH-DA, final concentration $5 \mu \mathrm{M})[16]$. $\left[\mathrm{Ca}^{2+}\right]_{\mathrm{i}}$ was detected with a calcium-binding dye Fluo-3 AM [17]. MMP was detected with 3-3'-dihexyloxacarbocyanine (DiOC6) [18]. The mixtures were incubated at $37^{\circ} \mathrm{C}$ for $30 \mathrm{~min}$ in the dark and washed twice with PBS, and the fluorescence intensity of the samples was measured in 5000 dissociated cells with an EPICS XL-MCL flow cytometer (Coulter, Miami, FL, USA) by gating FL1 (emission at $525 \mathrm{~nm}$ ).

\subsection{Apoptosis and Necrosis Detection}

(1) Determination of Necrotic Cell Death by Flow Cytometry. The number of necrotic cells was measured using the method described by Harrison et al. [17]. Briefly, propidium iodide (PI, final concentration $4.5 \mu \mathrm{g} / \mathrm{mL}$ ) was added to cells treated with KA $\left(10^{6}\right.$ cells $\left./ \mathrm{mL}\right)$ and then incubated for $20 \mathrm{~min}$ at room temperature in the dark. After washing twice with PBS, the fluorescence intensity of the samples was measured with an EPICS XL-MCL flow cytometer (Coulter) by gating FL3 (emission at $615 \mathrm{~nm}$ ) using 5000 dissociated cells. The results are expressed as the percentage of cell death compared with vehicle-treated controls.

(2) Determination of Apoptosis by DNA Fragmentation. DNA was extracted from the cells using the Blood and Tissue Genomic DNA Mini Kit (Viogene, Taipei, Taiwan). The percentage of DNA fragmentation was analyzed by conventional agarose gel electrophoresis as reported previously [19]. Twenty micrograms of DNA from each sample was electrophoresed on a $1.2 \%$ agarose gel containing $0.5 \%$ ethidium bromide at a $4 \mathrm{~V} / \mathrm{cm}$ gel length $(30 \mathrm{~V}$ for $6 \mathrm{~h})$. The gels, in the presence or absence of DNA "laddering" of approximately 200 base pairs, were then photographed under ultraviolet light.

(3) Determination of Apoptosis by Annexin V Staining. The ratio of apoptosis was assessed using Annexin V, as reported previously [20]. Specimens of cortex were diluted to a concentration of $1 \times 10^{5}$ cells $/ \mathrm{mL}$ with PBS. $20 \mu \mathrm{L}$ of cell suspension was spread onto a slide and $5 \mu \mathrm{L}$ FITC-Annexin $\mathrm{V}$ and $50 \mu \mathrm{L}$ Annexin-binding buffer (BD Biosciences) were added. After staining for $15 \mathrm{~min}$ at room temperature in the dark, the slides were observed under a fluorescence microscope (Axioskop; Zeiss, Germany) with an excitation filter of 515$560 \mathrm{~nm}$ and a barrier filter of $590 \mathrm{~nm}$. Images were captured using the Komet 3.1 image analysis system (Kinetic Imaging, Bromborough, UK).

2.5. Preparation of Sample for Two-Dimensional Gel Electrophoresis (2-DE). After the occurrence of apoptosis was confirmed by these tests, two KA-treated samples ( 0.5 and $5 \mu \mathrm{M}$ KA-induced excitotoxic insult for $3 \mathrm{~h}$ ) were added to a $1 \mathrm{~mL}$ lysis buffer containing $7 \mathrm{M}$ urea, $2 \mathrm{M}$ thiourea, 4\% 3-[(3-cholamidopropyl) dimethylammonio]1-propanesulfonate (Chaps), $40 \mathrm{mM}$ Tris, and $10 \mathrm{mM}$ dithiothreitol plus phosphatase/protease inhibitors $(1 \mathrm{mM}$ $\mathrm{Na}_{3} \mathrm{VO}_{4}, 1 \mathrm{mM}$ PMSF) on ice and shaken for 30 minutes to extract the proteins. The supernatant was purified using the Amersham 2D clean-up kit (GE Healthcare Biosciences, Australia) and the protein pellet was finally resuspended in a $250 \mu \mathrm{L}$ rehydration buffer (8 M urea, 2\% w/v CHAPS, $15 \mathrm{mM}$ DTT, and $0.5 \% \mathrm{v} / \mathrm{v}$ IPG buffer, $\mathrm{pH} 3-10)$. Total protein was determined using the Micro BCA Protein Assay reagent and bovine serum albumin as a standard.

Two-dimensional electrophoresis (2-DE) was performed as described previously [21]. The first dimension, isoelectric focusing (IEF), was performed using $18 \mathrm{~cm}$ immobilized $\mathrm{pH}$ gradient (IPG) gel strips ( $\mathrm{pH} 4-7)$. This dimension separates 
proteins in the mixture based on their isoelectric points (PI) following a stepwise incremental voltage program: $30 \mathrm{~V}$ for $16 \mathrm{~h}, 500 \mathrm{~V}$ for $1 \mathrm{~h}, 1 \mathrm{KV}$ for $1 \mathrm{~h}$, and $8 \mathrm{KV}$ for $4 \mathrm{~h}$, with a total power of $34 \mathrm{kV}-\mathrm{h}$. The second dimension was performed using $11 \%$ SDS polyacrylamide gels (Protean II xi cell, Bio$\mathrm{Rad}, \mathrm{CA}, \mathrm{USA}$ ) at $40 \mathrm{~mA} / \mathrm{gel}$ for $1 \mathrm{~h}$. The gels were then fixed in $40 \%$ ethanol and $10 \%$ acetic acid in water overnight and stained with $0.25 \% \mathrm{w} / \mathrm{v}$ silver nitrate solution containing $0.02 \%$ formaldehyde for $30 \mathrm{~min}$.

2.6. 2-DE Data Analysis. The stained 2-DE gels were scanned using ImageScanner operated by LABSCAN 3.01 software (Amersham Biosciences). Image analysis was carried out using the software IMAGEMASTER 2D (version 2002.1, Amersham Biosciences). Each spot intensity volume was processed using background subtraction and total spot volume normalization, which produced the spot volume percentage (\% vol.). Each cell sample $(0.5$ and $5 \mu \mathrm{M}$ KAinduced excitotoxic insult for $3 \mathrm{~h}$ ) was subjected to 2-DE three times to minimize run-to-run variation. A reference gel was artificially created and used to match corresponding protein spots between gels. Spot intensities (spot volume) were then normalized as a percentage of the total spot volume using spots that were present in all gels (\% vol.). Spots with a \% vol. ratio between the two groups of greater than 1.5 were regarded as dysregulated and were selected for subsequent destaining (50\% acetonitrile and $25 \mathrm{mM}$ ammonium bicarbonate). These samples were digested overnight at $37^{\circ} \mathrm{C}(10 \mu \mathrm{L}$ of $0.1 \mu \mathrm{g} / \mu \mathrm{L}$ of trypsin digestion buffer in $25 \mathrm{mM}$ ammonium bicarbonate). After centrifuging at $2000 \times \mathrm{g}$ for $10 \mathrm{~min}$, the supernatant was subjected to mass spectrometry analysis for protein identification. The in-gel digestion, mass spectrometry analysis, and database search were commissioned by the Departments of Environmental and Occupational Health, National Cheng Kung University College of Medicine, Taiwan.

2.7. Statistical Analysis. Flow cytometry data were analyzed by analysis of variance using SAS statistical software (SAS Institute, Inc.). Data from the different groups were compared using the one-way ANOVA method followed by Duncan's test $(P<0.01)$.

\section{Results}

3.1. ROS Changes in Dissociated Immature Cortical Cells Treated with KA. KA exhibited an excitotoxic effect by generating significant amounts of ROS in dissociated immature cortical cells at five different concentrations (ranging from $0.005 \mathrm{pM}$ to $500 \mu \mathrm{M}$ ) and over four different time periods (5, 30, 60, and $180 \mathrm{~min})$, as shown in Figures 1(a)-1(e). Compared to the untreated controls at the same time, the application of moderate and high doses of KA (0.5 pM, $50 \mathrm{nM}, 5 \mu \mathrm{M}$, and $500 \mu \mathrm{M})$ resulted in significantly higher ROS production. No significant change was detected in ROS generation at the lowest dose of KA $(0.005 \mathrm{pM})(P<$ 0.01 versus control). Compared to the group treated with a moderate dose of KA $(0.5 \mathrm{pM})$ group, ROS generation was markedly increased at 30, 60, and $180 \mathrm{~min}$ in the group treated with high concentrations of KA $(5$ and $500 \mu \mathrm{M})(P<0.01$ versus $0.5 \mathrm{pM}$ KA group) (Figure 1(f)). Comparison of ROS production at the same concentration of KA at different time periods showed that KA induced a time-dependent increase in intracellular ROS production.

\subsection{Changes in MMP in Dissociated Immature Cortical Cells} Treated with KA. Figures 2(a)-2(e) illustrate the effects of different doses of KA on excitotoxic changes in MMP at all time points. A significant reduction in MMP (indicated by an increased fluorescent intensity) in dissociated immature cortical cells occurred with all KA concentrations and incubation times compared to cells without KA administration $(P<0.01$ versus control). Treatment with $50 \mathrm{nM}$ of $\mathrm{KA}$ for 60 or $180 \mathrm{~min}$ and $5 \mu \mathrm{M}$ and $500 \mu \mathrm{M}$ of KA for $5,30,60$, or 180 min caused significant decreases in MMP compared to the moderate dose of KA $(0.5 \mathrm{pM} ; P<0.01$ versus $0.5 \mathrm{pM}$ KA group). In this study, there were significant differences in ROS production and decreased MMP in all KA groups.

\subsection{Changes in Intracellular $\left[\mathrm{Ca}^{2+}\right]$ in Dissociated Immature} Cortical Cells Treated with KA. KA-induced intracellular calcium changes and neurotoxicity were observed in cortical cells; however, there was no consistent KA concentration response (Figures 3(a)-3(e)). High concentrations of KA (5 and $500 \mu \mathrm{M})$ applied over $30 \mathrm{~min}$, moderate doses of $\mathrm{KA}$ ( $0.5 \mathrm{pM}$ and $50 \mathrm{nM})$, and $0.005 \mathrm{pM} \mathrm{KA}$ at four time points caused a rapid rise in $\left[\mathrm{Ca}^{2+}\right]_{\mathrm{i}}$ compared to untreated cells $(P<0.01$ versus control). However, the administration of high concentrations of KA $(5$ or $500 \mu \mathrm{M})$ for only $5 \mathrm{~min}$ significantly reduced intracellular $\mathrm{Ca}^{2+}$ levels $(P<0.01)$. When compared with $0.5 \mathrm{pM}$ KA group over $60 \mathrm{~min}$, there were significant increases in intracellular $\mathrm{Ca}^{2+}$ levels at the highest concentrations of KA (5 and $500 \mu \mathrm{M})$ and with moderately high concentrations of $\mathrm{KA}(P<0.015,500 \mu \mathrm{M}$ and $50 \mathrm{nM}$ KA versus $0.5 \mathrm{pM}$ KA group) (Figure 3(f)). There were large decreases in intracellular $\mathrm{Ca}^{2+}$ levels in cells exposed to the highest concentrations of KA (5 and $500 \mu \mathrm{M}$ ) compared to cells exposed to $0.5 \mathrm{pM} \mathrm{KA}$ for 5 or $30 \mathrm{~min}$. Prolonged exposure of cultured cortical cells to the same concentration of KA did not produce a time-dependent increase in intracellular calcium ion levels.

\subsection{Determination of Necrotic Cell Death of Immature Cortical} Cells Treated with KA. The excitotoxicity-associated necrotic cell death following KA treatment was quantified using the DNA fluorescent dye, propidium iodide (PI). Our results showed that KA induced significantly more necrotic cell death ( $>70 \%$ of the neurons) at higher concentrations (5 and $500 \mu \mathrm{M})$ applied over $180 \mathrm{~min}$ than those in control group $(P<0.01 ;$ Figure 4$)$. If the same two concentrations of KA (5 and $500 \mu \mathrm{M}$ ) were applied over $30 \mathrm{~min}$, the percentage of necrotic cells increased from approximately $8 \%$ to $12 \%$. Therefore, these results indicate that necrotic cell death is associated with KA and there is a significant exposure-time effect at high KA concentrations. No significant effects of KA on necrotic cell death were found at lower concentrations 


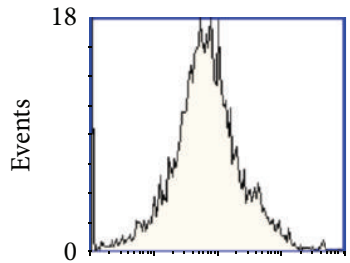

FL 1 LOG

Kainic acid

$\Longleftarrow$ Control

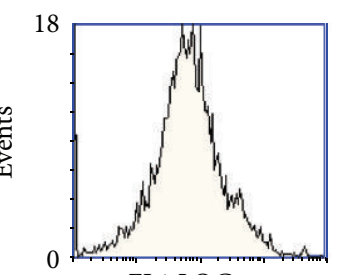

FL1 LOG

Kainic acid

Control

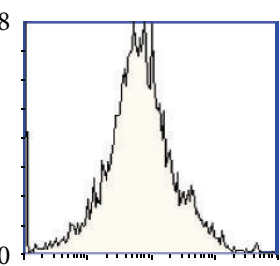

FL1 LOG

Kainic acid

$\Longleftarrow$ Control

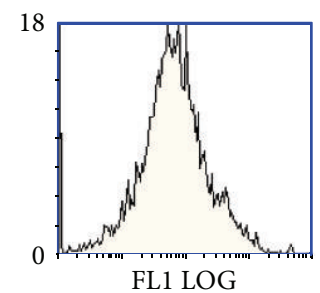

Kainic acid

Control

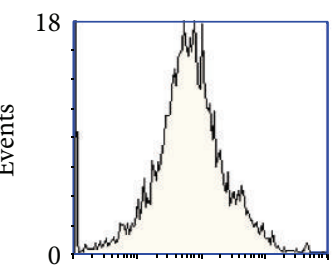

FL1 LOG

Kainic acid

Control

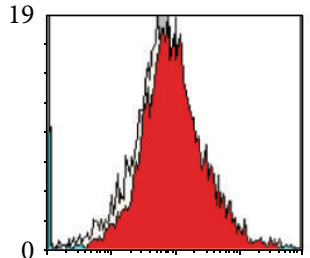

FL 1 LOG

$\rightleftharpoons$ Control
$=5 \mathrm{~min}$

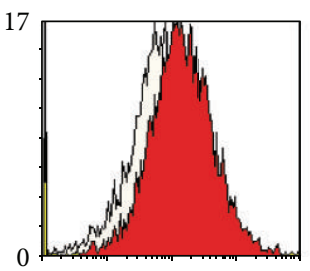

FL1 LOG

Control

$5 \mathrm{~min}$

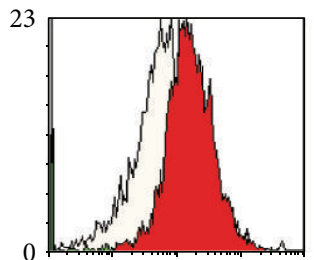

FL1 LOG

Control

$5 \mathrm{~min}$

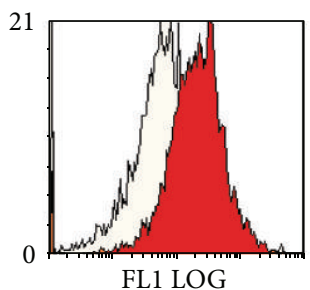

$\Longleftarrow$ Control
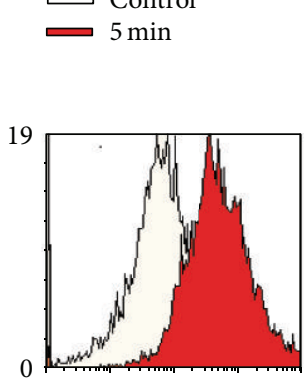

FL1 LOG

Control

ए $5 \mathrm{~min}$

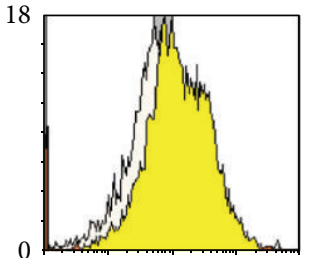

FL 1 LOG

Control

(a)

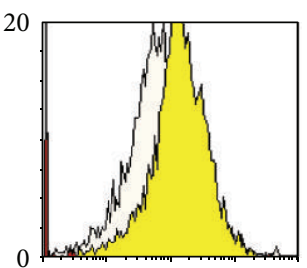

FL1 LOG

Control

30 min

(b)

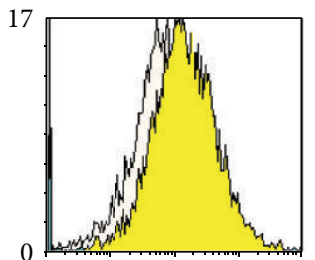

FL1 LOG

Control

(c)

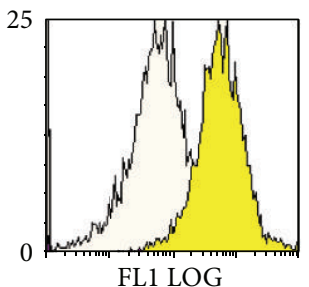

Control

(d)

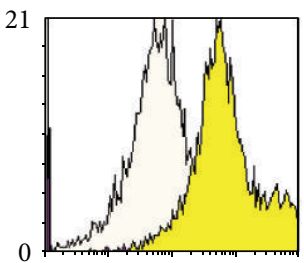

FL1 LOG

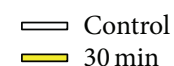

(e)

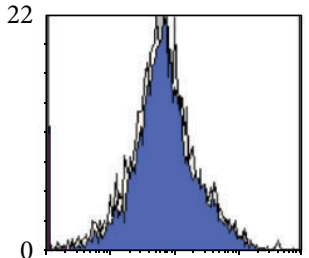

FL 1 LOG

Control

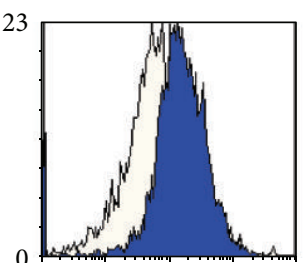

FL1 LOG

Control

$60 \mathrm{~min}$

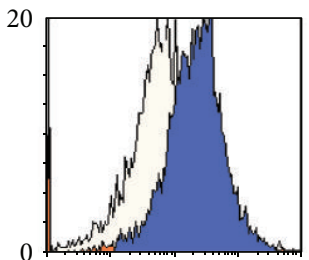

FL1 LOG

Control

$60 \mathrm{~min}$

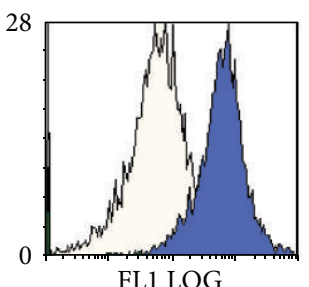

Control

$60 \mathrm{~min}$

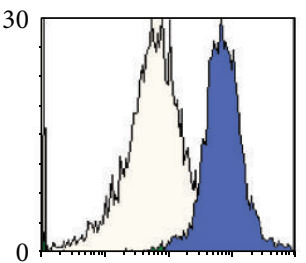

FL1 LOG

Control

ए $60 \mathrm{~min}$

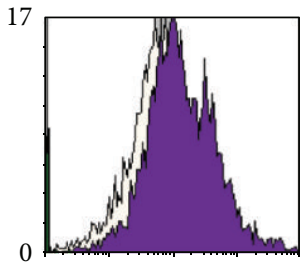

FL 1 LOG

Control

$180 \mathrm{~min}$

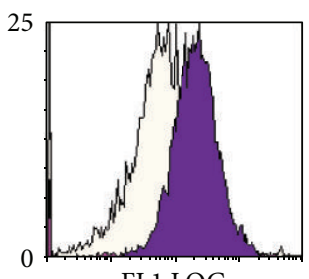

FL1 LOG

Control

$180 \mathrm{~min}$

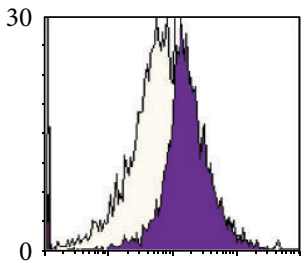

FL1 LOG

Control

$180 \mathrm{~min}$

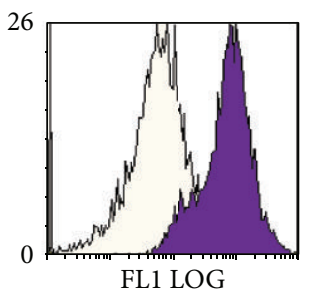

Control

$180 \mathrm{~min}$

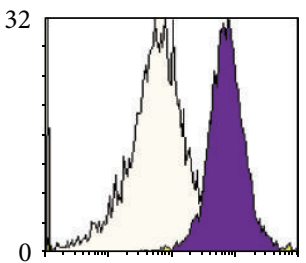

FL1 LOG

Control

— $180 \mathrm{~min}$

FIgure 1: Continued. 


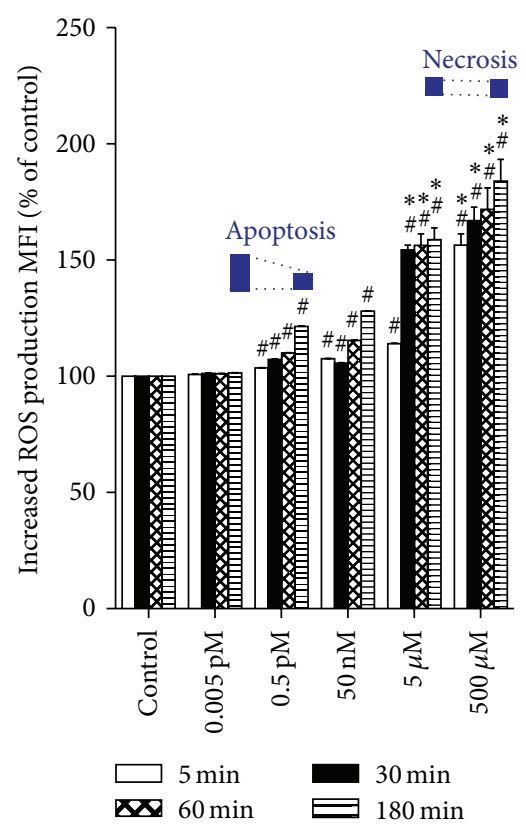

(f)

FIGURE 1: Comparison of intracellular reactive oxygen species (ROS) measured by flow cytometry following exposure to kainic acid (KA) over different time periods. (a-e) Representative fluorescence histograms obtained from dissociated cortical neurons $\left(10^{6} \mathrm{cells} / \mathrm{mL}\right)$ from 14-day-old rat brains incubated with $2^{\prime}, 7^{\prime}$-dichlorofluorescein diacetate in the presence of $0.005 \mathrm{pM}, 0.5 \mathrm{pM}, 50 \mathrm{nM}, 5 \mu \mathrm{M}$, and $500 \mu \mathrm{M} \mathrm{KA}$ for 5 (red), 30 (yellow), 60 (blue), and $180 \mathrm{~min}$ (purple). The white curve represents the background fluorescence of untreated neurons; the colored curves represent the increased fluorescent intensity of neurons following KA treatment (a shift to the right versus white curve). (f) Bar graphs of ROS levels (mean \pm SE) expressed as percentage change in mean fluorescence intensity (MFI) from controls. Experiments were performed in triplicate, and statistical analyses of the data were performed using ANOVA. Data are expressed as percentage change from controls. ${ }^{\#} P<0.01$ compared with the respective time period in the control group. ${ }^{*} P<0.01$ compared with the respective time period in the 0.5 pM KA group. Apoptosis and necrosis labels indicate the degrees of cell death at 180 min of treatment.

of KA (0.005 pM, $0.5 \mathrm{pM}$, and $50 \mathrm{nM})$, even with incubation periods of $180 \mathrm{~min}$.

\subsection{Determination of Apoptosis by Annexin V and DNA Frag-} mentation Assays. KA-induced excitotoxic apoptosis in rat cortical cells was confirmed by both DNA fragmentation and Annexin V. DNA fragmentation is the nuclear hallmark of apoptosis and was found to occur in this study following $3 \mathrm{hr}$ of $0.5 \mathrm{pM}$ KA exposure. Low levels of DNA fragmentation occurred after $50 \mathrm{nM}$ KA exposure. Neither controls nor cells treated with $5 \mu \mathrm{M}$ KA demonstrated DNA fragmentation (Figure 5). The Annexin $\mathrm{V}$ assay produced the same result in cells exposed to $50 \mathrm{nM} \mathrm{KA}$ (Figure 6). Using fluorescence microscopy, a high percentage of Annexin V-positive cells (approximately 95\%) were observed in the samples treated with $0.5 \mathrm{pM}$ KA for $180 \mathrm{~min}$ (Figures 6(a) and 6(b)). Fewer Annexin V-positive cells (approximately 8\%) occurred in the samples treated with $50 \mathrm{nM}$ KA for $180 \mathrm{~min}$ (Figures 6(c) and 6(d)). There were no Annexin V-positive cells among the control samples (Figures 6(e) and 6(f)). Through the above measures, apoptosis was found to be induced at moderate concentrations of $\mathrm{KA}(0.5 \mathrm{pM}$ and $50 \mathrm{nM})$ and necrosis at high concentrations $(5 \mu \mathrm{M})$ in rat cortical cells.
3.6. Candidate Proteins Associated with Apoptosis versus Necrosis under Excitotoxic Conditions. The protein spots that differed between the apoptotic and necrotic groups were subjected to mass spectrometry for protein identification. Five 2 -DE protein spots revealed significant differences between the two groups (Figure 7). Table 1 provides a summary of four proteins, heat shock protein 70, 3-mercaptopyruvate sulfurtransferase, tubulin $\beta-5$, and pyruvate dehydrogenase E1 component subunit beta, which were significantly upregulated (1.5-fold or greater) in cells that had undergone apoptotic death. There were no significant differences in the intensities of guanine nucleotide binding protein $(<1.5$-fold $)$ between the apoptosis and necrosis groups. Mass spectrometry was unable to identify the remaining three spots (data not shown), indicating that there were no MS/MS data matching with the sequences from a mass spectra database search. Mass spectrometry of these proteins and the probability based Mowse scores obtained with the Mascot search engine are shown in Figure 8.

\section{Discussion}

In our previous study, we used pilocarpine, another cholinergic neurotoxin, to induce experimental models of status 


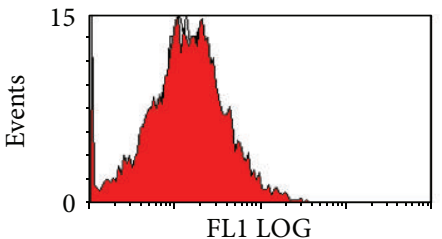

Kainic acid

Control
$=5 \mathrm{~min}$

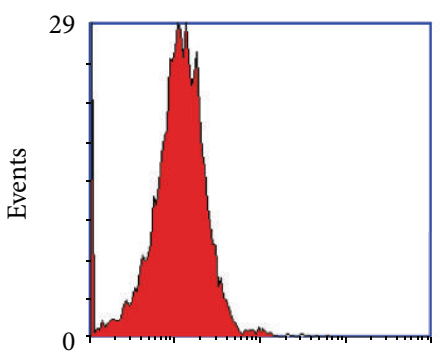

FL1 LOG

Kainic acid

Control

— $5 \mathrm{~min}$

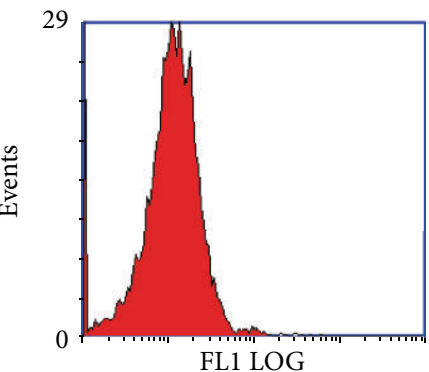

Kainic acid

Control

$5 \mathrm{~min}$

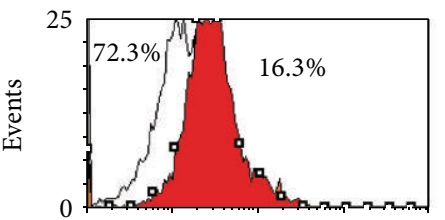

FL1 LOG

Kainic acid

Control

— $5 \mathrm{~min}$

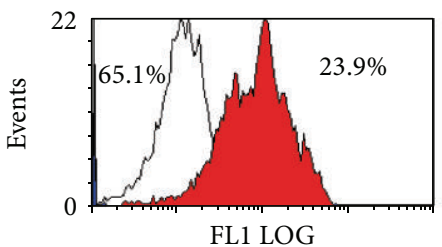

Kainic acid

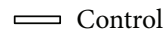

$5 \mathrm{~min}$

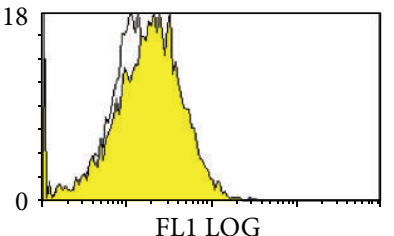

Control

ש $30 \mathrm{~min}$

Control

— $60 \mathrm{~min}$

(a)

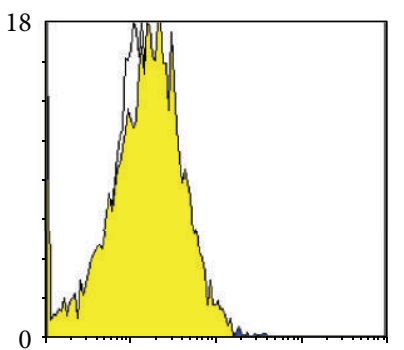

FL1 LOG

Control

ऍ $30 \mathrm{~min}$

(b)

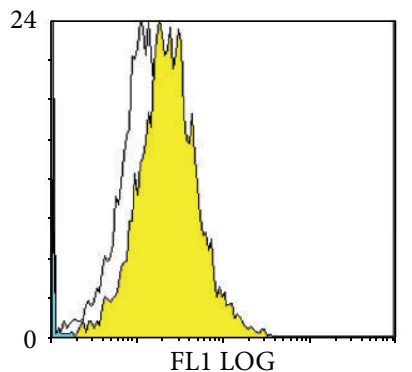

Control

ए $30 \mathrm{~min}$

(c)

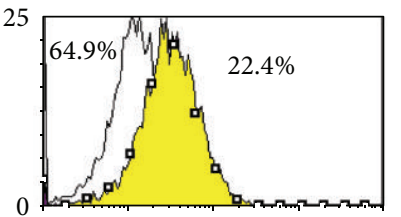

FL1 LOG

Control

ए $30 \mathrm{~min}$

$\smile$ Contro

(d)
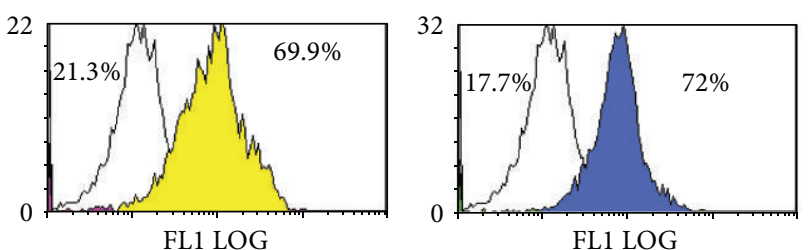

FL1 LOG

Control

— $60 \mathrm{~min}$

Control

ऍ $30 \mathrm{~min}$

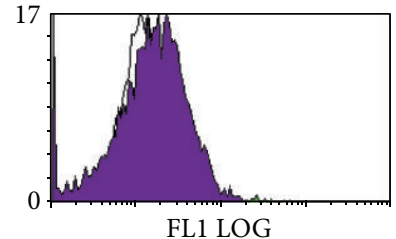

FL1 LOG

$\Longleftarrow$ Control

工 $180 \mathrm{~min}$

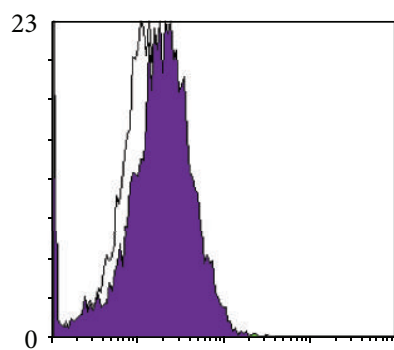

FL1 LOG

Control

$180 \mathrm{~min}$

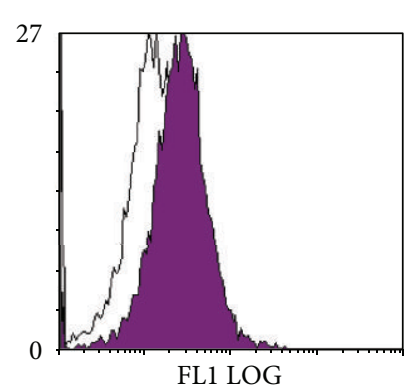

Control

$180 \mathrm{~min}$

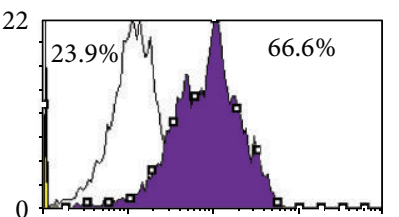

FL1 LOG

Control

$180 \mathrm{~min}$

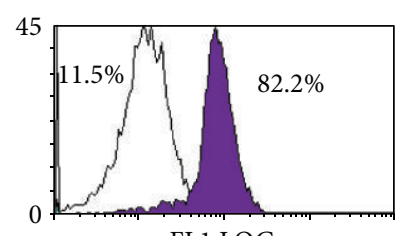

FL1 LOG

(e)

FIGURE 2: Continued. 


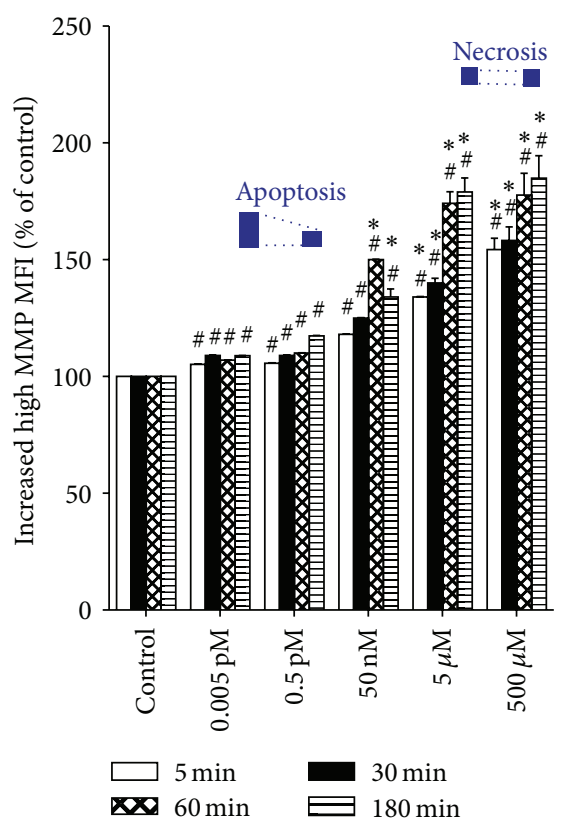

(f)

FIGURE 2: Comparison of mitochondrial membrane potential (MMP) measured by flow cytometry following exposure to kainic acid (KA) over different time periods. (a-e) Representative fluorescence histograms obtained from dissociated cortical neurons $\left(10^{6} \mathrm{cells} / \mathrm{mL}\right)$ from 14-day-old rat brains incubated with 3-3'-dihexyloxacarbocyanine in the presence of $0.005 \mathrm{pM}, 0.5 \mathrm{pM}, 50 \mathrm{nM}, 5 \mu \mathrm{M}$, and $500 \mu \mathrm{M}$ KA for 5 (red), 30 (yellow), 60 (blue), and $180 \mathrm{~min}$ (purple). The white curves represent the background fluorescence of untreated neurons; the colored curves represent the increased loss of MMP from cells (indicated by an increase in $535 \mathrm{~nm}$ fluorescence intensity versus white curve) following KA treatment. (f) Bar graphs of MMP intensity (mean \pm SE) expressed as the percentage change in mean fluorescence intensity (MFI) from controls. Experiments were performed in triplicate, and statistical analyses of the data were performed using ANOVA. Data are expressed as percentage (\%) change from controls. ${ }^{\#} P<0.01$ compared with the respective time period in the control group. ${ }^{*} P<0.01$ compared with the respective time period in the $0.5 \mathrm{pM}$ KA group. Apoptosis and necrosis labels indicate the degrees of cell death at $180 \mathrm{~min}$ of treatment.

TABLE 1: Summary of five differentially regulated proteins in kainic acid-induced apoptosis, compared to KA-induced necrosis, as detected by two-dimensional differential in-gel electrophoresis (DIGE) and mass spectrometry.

\begin{tabular}{|c|c|c|c|c|c|c|}
\hline Spot number & Protein & $\begin{array}{l}\text { Accession (ID) } \\
\text { number }^{\mathrm{a}}\end{array}$ & $\mathrm{MW}(\mathrm{Da})^{\mathrm{b}} / \mathrm{PI}$ & Change $^{c}$ & $\begin{array}{c}\text { Sequence } \\
\text { Coverage }(\%)^{\mathrm{d}}\end{array}$ & $\begin{array}{l}\text { Mowse } \\
\text { score }^{\mathrm{e}}\end{array}$ \\
\hline $1^{*}$ & $\begin{array}{l}\text { 3-Mercaptopyruvate } \\
\text { sulfurtransferase }\end{array}$ & NP_620198.1 & $32809 / 5.88$ & 1.6 & $13 \%$ & 67 \\
\hline $2^{*}$ & Pyruvate dehydrogenase beta & NP_001007621.1 & $35842 / 6.20$ & 1.7 & $27 \%$ & 185 \\
\hline $3^{*}$ & Tubulin beta 5 & NP_035785.1 & $49639 / 4.78$ & 1.8 & $9 \%$ & 112 \\
\hline $4^{*}$ & Heat shock protein 60 (HSP60) & CAA37654.1 & $57890 / 5.35$ & 2.2 & $19 \%$ & 252 \\
\hline 5 & $\begin{array}{l}\text { Guanine nucleotide binding } \\
\text { protein }\end{array}$ & NP_001013932.1 & $37339 / 5.74$ & 1.2 & $16 \%$ & 122 \\
\hline
\end{tabular}

\footnotetext{
* Significantly upregulated proteins demonstrated a greater than 1.5 -fold increase in expression.

${ }^{a}$ Reference for protein identification from the protein database at the National Center for Biotechnical Information (NCBI).

${ }^{\mathrm{b}} \mathrm{MW}$ : molecular weight.

${ }^{c}$ Intensity of spots from two samples run in the 2D-DIGE gel as measured by IMAGEMASTER 2D software.

${ }^{\mathrm{d}}$ Sequence coverage (\%) indicates the number of amino acids spanned by the assigned peptides divided by the sequence length.

${ }^{\mathrm{e}}$ Mowse score indicates the probability that the match between the database and a spectrum is a random event.
}

epilepticus and found that pilocarpine induced two types of seizures: severe prolonged seizures and repeated seizures [22]. The findings of the study indicated that the animals in the group with prolonged seizures had excessive levels of reactive oxygen species and malondialdehyde production and lower activities of superoxide dismutase and catalase as compared with the group with repeated seizures. Therefore, in the current study we aimed to investigate the proteins involved in different types of oxidative damage in the brain. We found that the two modalities of cortical cell death (apoptosis and necrosis) in dissociated immature cortical cells exposed to excitotoxic insults were present by flow cytometry and were confirmed by PI staining, DNA fragmentation, and Annexin $\mathrm{V}$ assay. 2-DE gel analysis and mass spectrometry 


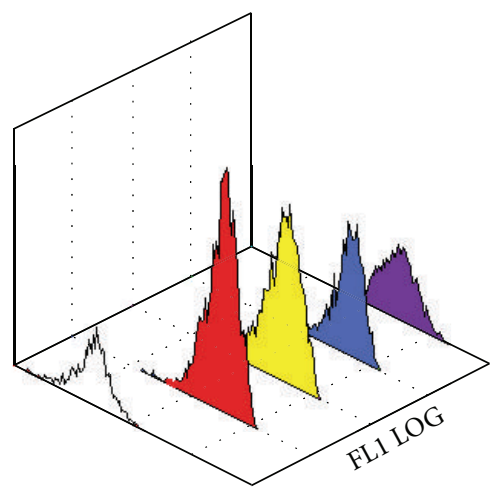

(a)

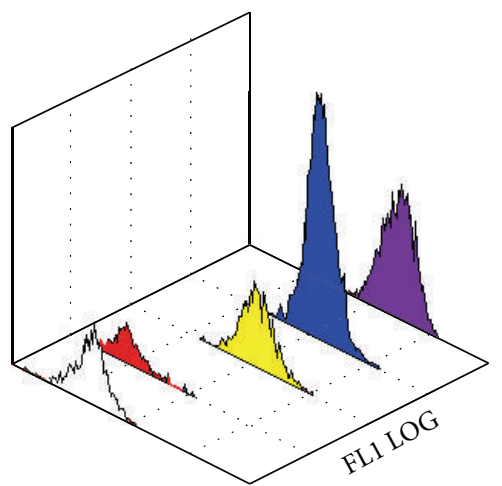

Kainic acid

$\Longleftarrow$ Control

$5 \mathrm{~min}$

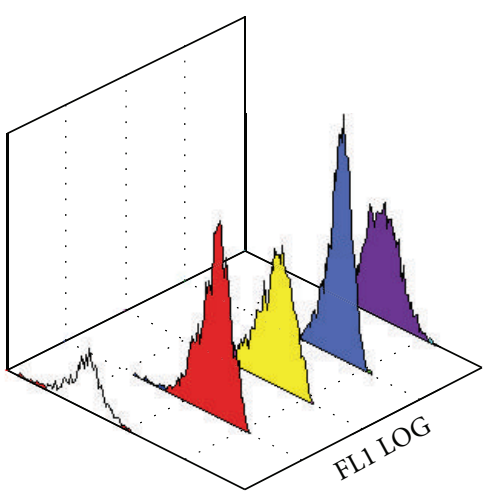

(b)

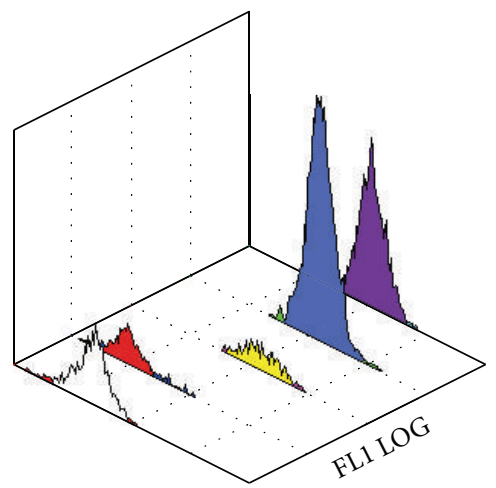

Kainic acid

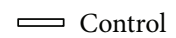

$5 \mathrm{~min}$

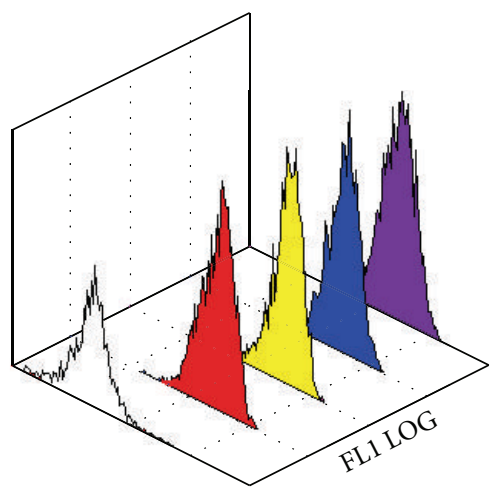

(c)
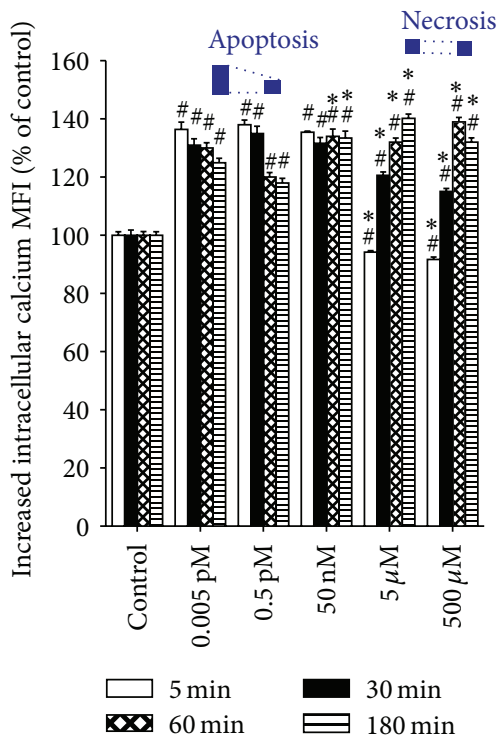

(f)

FIGURE 3: Comparison of intracellular calcium ion concentration $\left(\left[\mathrm{Ca}^{2+}\right]_{\mathrm{i}}\right)$ measured by flow cytometry following exposure to different doses of kainic acid (KA) over different time periods. (a-e) Representative three-dimensional graph obtained from dissociated cortical neurons $\left(10^{6}\right.$ cells $\left./ \mathrm{mL}\right)$ from 14 -day-old rat brains incubated with Fluo- $3 \mathrm{AM}$ in the presence of $0.005 \mathrm{pM}, 0.5 \mathrm{pM}, 50 \mathrm{nM}, 5 \mu \mathrm{M}$, and $500 \mu \mathrm{M} \mathrm{KA}$ for 5 (red), 30 (yellow), 60 (blue), and $180 \mathrm{~min}$ (purple). The white curves represent the background fluorescence of untreated neurons; the colored curves represent the decreased or increased fluorescent intensity of neurons following KA treatment (a shift to the left or right, resp., versus white curve). (f) Bar graphs of intracellular calcium concentration (mean \pm SE) expressed as the percentage change in mean fluorescence intensity (MFI) from controls. Experiments were performed in triplicate, and statistical analyses of the data were performed using ANOVA. Data are expressed as percentage change from controls. ${ }^{\#} P<0.01$ compared with the respective time period in the control group. ${ }^{*} P<0.01$ compared with the respective time period in the $0.5 \mathrm{pM}$ KA group. Apoptosis and necrosis labels indicate the degrees of cell death at $180 \mathrm{~min}$ of treatment.

demonstrated differential protein profiles in apoptosis and necrosis, enabling elucidation of the regulated mechanisms of cell death.

ROS are important for the mediation of cell survival and proliferation. However, excessive ROS generation is a well-known major contributing factor to excitatory amino acid neurotoxicity and neurodegenerative diseases resulting from oxidative stress $[1,23]$. In this study, quantitative flow cytometry was used to evaluate the extent of oxidative stress in dissociated cortical cells in rats exposed to KAinduced excitotoxicity. An increase in intracellular ROS levels occurred in our in vitro KA models of excitotoxicity. An association between excitotoxicity and an increase in ROS has also been demonstrated in previous in vivo studies $[1$, 24]. Large amounts of ROS represent the main cause of cell damage and ultimately promote cell death [25]. Time- and dose-dependent effects of KA on ROS production in cortical cultures are consistent with the findings from previous reports in hippocampal cultures [26]. In cortical cultures, high concentrations of KA ( 5 and $500 \mu \mathrm{M}$ ) promoted higher levels of ROS production than those found in cells exposed to moderate KA concentrations $(0.5 \mathrm{pM})$. Furthermore, KA also induced a time-dependent increase in intracellular ROS production.

Mitochondria, the site of ATP generation, are thought to be involved in the pathway to cell death through changes to 


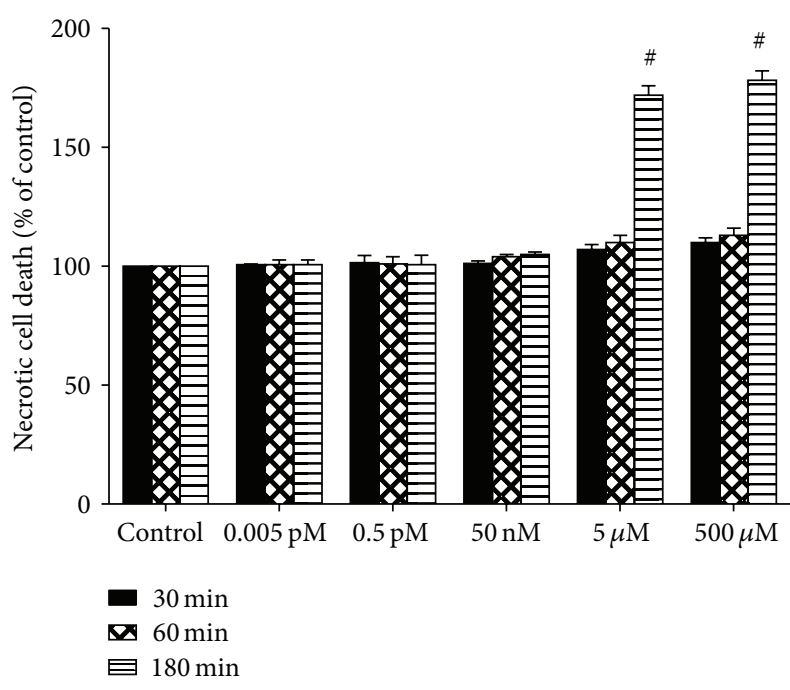

FIgURE 4: Effects of kainic acid (KA) on necrotic cell death measured using propidium iodide (PI) staining and flow cytometry of dissociated cortical neurons $\left(10^{6}\right.$ cells $\left./ \mathrm{mL}\right)$ from 14 -day-old rat brains exposed to $0.005 \mathrm{pM}$ to $500 \mu \mathrm{M}$ KA for $5,30,60$, or $180 \mathrm{~min}$. Bar graphs show the amount of necrotic cell death (mean \pm SE) expressed as the percentage change in mean fluorescence intensity (MFI) from controls. Experiments were performed in triplicate, and statistical analyses of the data were performed using ANOVA. Data are expressed as the percentage change from controls. ${ }^{\#} P<0.01$ compared with the respective time period in the control group.

or loss of MMP $[4,27]$. The findings of the present study are consistent with previous studies that have demonstrated depolarization of mitochondrial membranes in injured cells in response to activation of metabotropic glutamate receptors $[28,29]$. In another study, MMP levels were reduced in cells and cells became less viable after exposure to high concentrations of carbonyl cyanide 3-chlorophenylhydrazone [30]. The type of cell death invoked might depend on the intensity of the stimulus [31]. Increased ROS generation accompanied by mitochondrial damage participates in neuronal cell death.

Since the first reported cell death due to excitotoxic effects in the CNS in 1969, it has been shown that alterations in calcium homeostasis play key roles in excitotoxicity $[3,32]$. In this study, an increase in $\left[\mathrm{Ca}^{2+}\right]_{\mathrm{i}}$ occurred in cells exposed to KA treatment as compared with untreated cells. However, a decrease in $\left[\mathrm{Ca}^{2+}\right]_{\mathrm{i}}$ was also observed in cells exposed to high doses of KA ( 5 and $500 \mu \mathrm{M})$ for 5 minutes. A similar finding was reported by Youn and Randić [33], who discovered that application of KA ( $3 \mu \mathrm{M}, 2 \mathrm{~min})$ significantly depressed C fiber monosynaptic excitatory postsynaptic potentials through the kainate receptor, GluR5. It is likely that in the present study the varying effects of different doses of KA on $\left[\mathrm{Ca}^{2+}\right]_{\mathrm{i}}$ were due to the selection of metabotropic and ionotropic receptor entry into cells. In the CNS, $\mathrm{Ca}^{2+}$ influx via receptor-mediated mechanisms reportedly mediates cell death [34]. This in turn results in the activation of a variety of intracellular signals and, ultimately, different neurotoxic effects. One study suggested that excessive $\mathrm{Ca}^{2+}$ loading contributes to cell death in some cell types [35]. In this study,

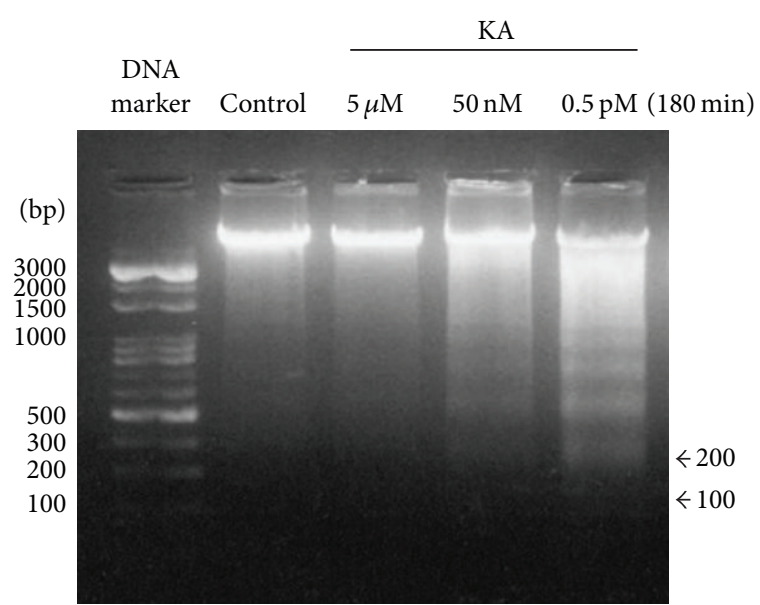

FIGURE 5: DNA ladder formation shown by gel electrophoresis. DNA was prepared from dissociated cortical cells from neonatal rats (P14) exposed to $0.5 \mathrm{pM}, 50 \mathrm{nM}$, and $5 \mu \mathrm{M}$ kainic acid (KA) for $180 \mathrm{~min}$, as well as from a control group. The DNA mixture was separated by $1.5 \%$ agarose gel. Lane 1 shows no DNA fragments in the cells from untreated dissociated cortical cells. Lanes 2 and 3 show no DNA fragments in the dissociated cortical cells treated with $5 \mu \mathrm{M}$ and $50 \mathrm{nM}$ KA for $180 \mathrm{~min}$. Lane 4 shows DNA fragments from dissociated cortical cells treated with $0.5 \mathrm{pM} \mathrm{KA}$ for $180 \mathrm{~min}$.

excessive $\mathrm{Ca}^{2+}$ loading occurred after exposure to a high concentration of KA for over $60 \mathrm{~min}$. Excessive $\mathrm{Ca}^{2+}$ loading may therefore contribute to mitochondrial depolarization followed by the opening of permeability transition pores and a concurrent significant increase in ROS levels. Based on the theory that injurious stimuli of a lesser amplitude than those causing necrosis in the same cells induce apoptosis [36], 5 and $500 \mu \mathrm{M}$ concentrations of $\mathrm{KA}$ and a $0.5 \mathrm{pM}$ concentration of $\mathrm{KA}$ applied for $3 \mathrm{~h}$ may result in different types of oxidative stress.

In this study, high concentrations of KA ( 5 and $500 \mu \mathrm{M}$ ) caused an increase in the percentage of necrotic cells after 3 hours of exposure, which was confirmed by PI staining. Results obtained by flow cytometry demonstrated the presence of both necrotic and nonnecrotic cells in these samples. A widely accepted biomarker of apoptosis is Annexin V [19]. In the current study, almost $95 \%$ of cells underwent KAinduced cell death following exposure to $0.5 \mathrm{pM} \mathrm{KA}$ for $3 \mathrm{~h}$ and demonstrated apoptotic bodies (fluorescence signals) under light and fluorescence microscopy and Annexin V assay. In contrast, only a few apoptotic cells were observed in cells exposed to $50 \mathrm{nM} \mathrm{KA}$ for $3 \mathrm{~h}$, and no apoptotic cells were observed in the control cells. The presence of DNA ladders, or internucleosomal genomic DNA fragmentation, is a biochemical hallmark of apoptosis and was visualized in this study using agarose gel electrophoresis in cells treated for $3 \mathrm{~h}$ with $0.5 \mathrm{pM}$ KA. However, the control cells remained dark without any DNA laddering, and no typical ladders of DNA fragments occurred in necrotic cells ( $5 \mu \mathrm{M} \mathrm{KA}$ for $3 \mathrm{~h}$ ). From the above results, it can be inferred that KA led to cortical cell death after 3 hours of exposure via either apoptosis or necrosis, depending on the concentration administered. 


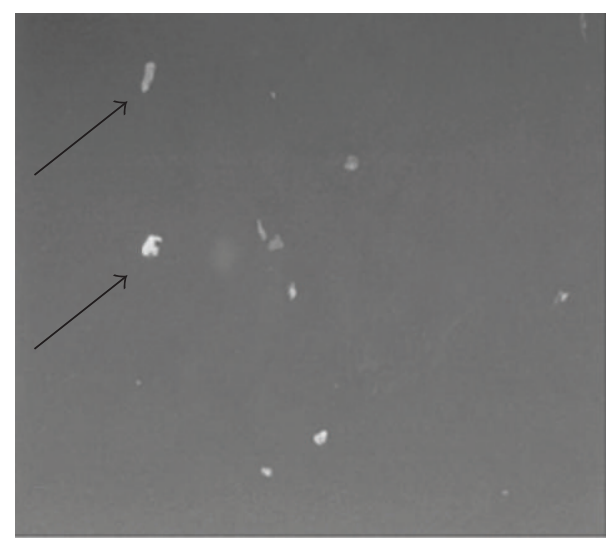

(a)

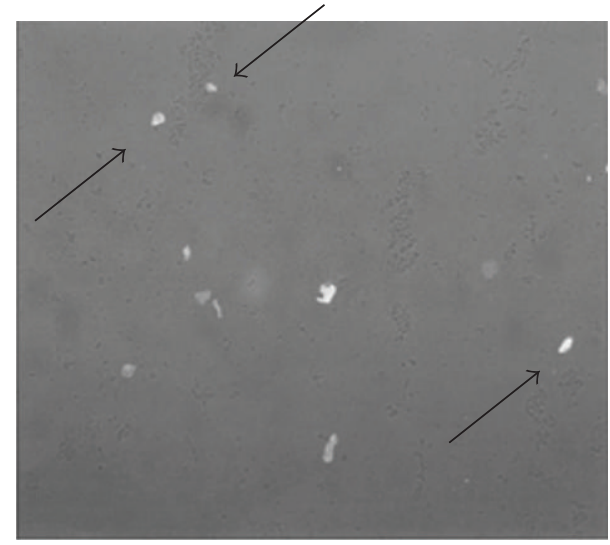

(c)

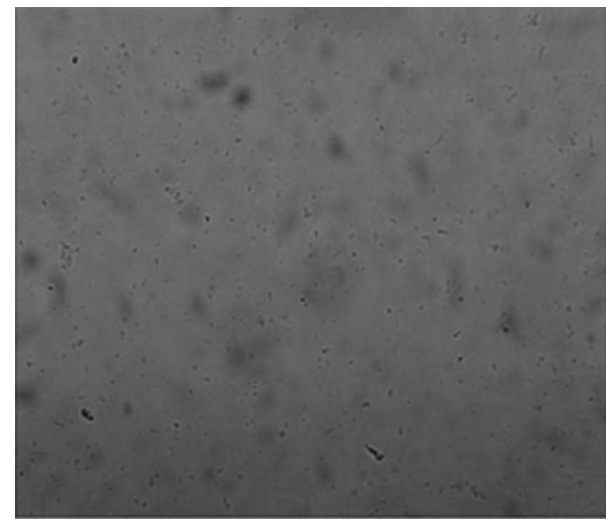

(e)

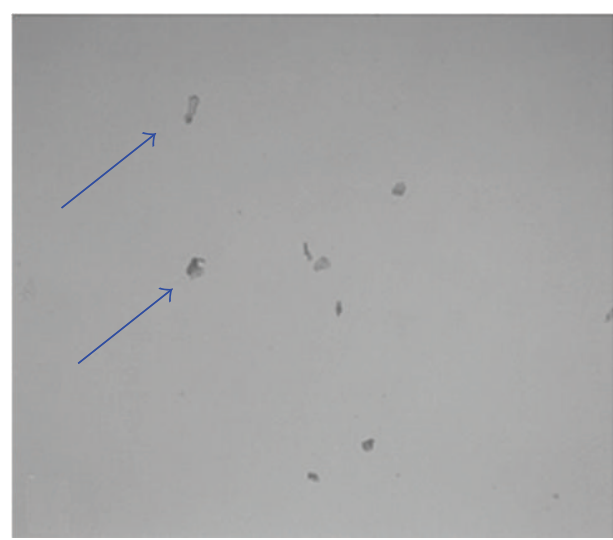

(b)

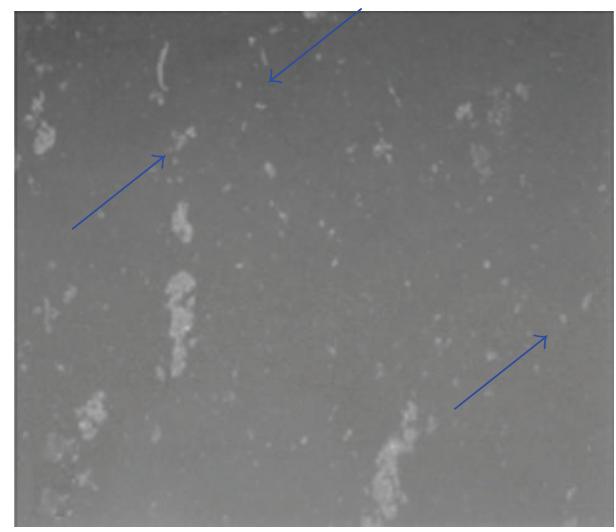

(d)

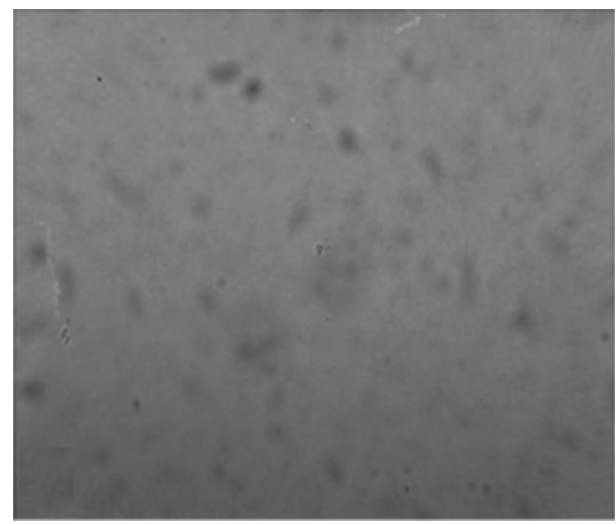

(f)

FIGURE 6: Morphology of apoptotic bodies in cells treated with $0.5 \mathrm{pM}$ and $50 \mathrm{nM}$ kainic (KA) acid and control cells. $20 \mu \mathrm{L}$ of dissociated cortical neurons $\left(1 \times 10^{5}\right.$ cells $\left./ \mathrm{mL}\right)$ exposed to $0.5 \mathrm{pM}((\mathrm{a})$ and $(\mathrm{b}))$ and $50 \mathrm{nM}$ (c and d) KA for 180 min and control cells ((e) and (f)) were spread onto a slide and $5 \mu \mathrm{L}$ of FITC-Annexin V and $50 \mu \mathrm{L}$ Annexin-binding buffer were added. The slides were subsequently analyzed using fluorescence microscopy ((a), (c), and (e)) or light microscopy ((b), (d), and (f)) for the detection of apoptosis. Apoptotic cells (Annexin V-positive, black arrows) were visualized in KA-treated groups ((a) and (c)) under fluorescence microscopy but were not detected in control cells (e). Blue arrows indicate the corresponding Annexin V-positive cells in KA-treated groups as seen under light microscope.

The result is consistent with the finding of an in vivo epileptic study showing that the apoptotic component of seizureinduced neuronal death in the high-dose KA group versus the low-dose KA group is insult duration- or severity-dependent [37].
Identification of death-mediating factors through a model of excitotoxicity has the potential to aid the prediction of outcomes and lead to better targeting of interventions and management strategies. Thus, the present study aimed to identify and characterize key proteins involved in 


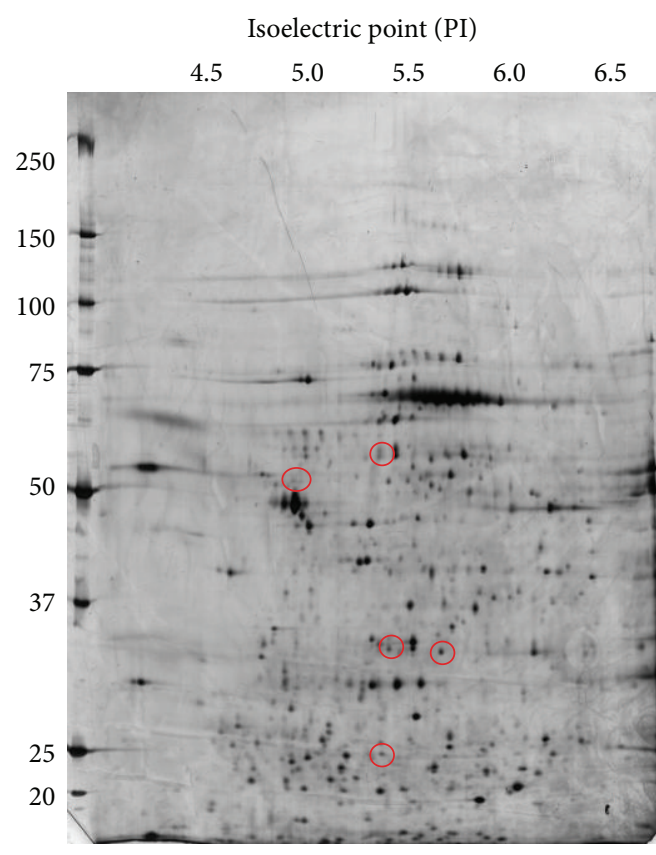

(a)

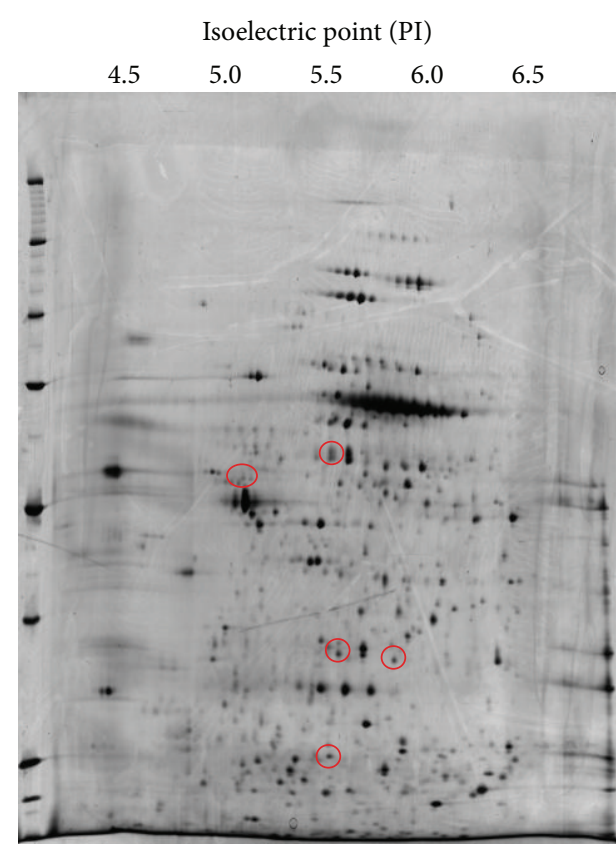

(b)

Figure 7: Comparison of electrophoretic protein profiles from apoptotic and necrotic cells. Following 180 min of treatment with 0.5 pM and $5 \mu \mathrm{M}$ kainic acid (KA), each dissociated cortical neuron cell lysate was separated into three different two-dimensional gel electrophoresis (2$\mathrm{DE})$ runs and stained with silver-stain. Figures are from representative gels demonstrating typical protein profiles of $5 \mu \mathrm{M}$ induced necrotic cells (a) and 0.5 pM KA-induced apoptotic cells (b). More than 1500 protein spots were routinely detected. The red circles indicate protein spots that were altered significantly by at least 1.5 -fold with a resulting increase in apoptotic cells compared with necrotic cells based on data from at least three independent gels $(P<0.05)$.

apoptotic versus necrotic cell death. 2D gel electrophoresis and mass spectrometry- (MS-) based proteomics were used to analyze KA-induced apoptosis and necrosis by examining differences in protein expression profiles. Proteins spots in which the silver intensity was increased by more than 1.5 -fold in KA-induced apoptosis compared with the same protein in necrotic cells under MS spectrometry were selected for analysis. Analyses identified one such spot as tubulin. Tubulin is, reportedly, an antiapoptotic protein involved in the apoptotic morphology. Previous research has suggested that the levels of tubulin mRNA transiently increase during apoptosis and that events occurring downstream from tubulin binding are critical for the generation of apoptosis [38]. Tubulin is also the biochemical target for several anticancer drugs [39]. Pyruvate dehydrogenase E1 component subunit beta, also known as an antiapoptotic protein, was significantly induced in response to excitotoxicity in this study. Its upregulation in KA insult-induced apoptotic death indicated a relative resistance to KA treatment. This response was also observed by Gerner and coworkers [40]. Pyruvate dehydrogenase acts as a bridge between glycolysis and the tricarboxylic acid cycle [41]. Its increase in the present study indicated the activation of the aerobic pathway required for apoptosis, as opposed to pathways involved in necrosis or critical illnesses. These results are consistent with those of Concannon and colleagues [42], who found that AMPK activation and Bim couple transient energy depletion occurred in response to stress-induced neuronal apoptosis in excitotoxicity. Pyruvate dehydrogenase also has a role in other conditions, such as cardiac ischemia and reperfusion injury [43]. Even postischemic hearts show improvement after pharmacological stimulation with pyruvate dehydrogenase [44]. In addition, we observed an increase in the level of a third protein, 3-mercaptopyruvate sulfurtransferase. This is reportedly an antioxidant protein with important roles in the maintenance of redox homeostasis and the production of hydrogen sulfide $\left(\mathrm{H}_{2} \mathrm{~S}\right)$ in normal tissues including the brain [45]. $\mathrm{H}_{2} \mathrm{~S}$ is a synaptic modulator and neuroprotectant and may protect the heart against ischemic injury by a pathway involving protein kinase $\mathrm{C}$ [46]. The final protein that exhibited the greatest increase in expression (2.2-fold) in apoptotic cells compared to necrotic cells was heat shock protein 60 (HSP60). HSP70, a cytosolic HSP, plays an antiapoptotic role in excitotoxicity, cerebral ischemia, and myocardial injury and has been intensively investigated. In contrast, mitochondrial matrix HSP60 is more controversial and has been reported to have both antiapoptotic and proapoptotic effects on cells. A proapoptotic role of HSP60 was found in surgical specimens from patients with intractable epilepsy, whereas the antiapoptotic gene $\mathrm{Bcl}$ 2 was downregulated to less than $50 \%$ of the normal level [47]. Similar to our results, Kirchhoff et al. [48] suggested that overexpression of HSP60 exerted an antiapoptotic effect to increase the survival rate of cardiac myocytes undergoing myocardial injury. These results indicated that the dual role of HSP60 is mediated through its interaction with other heat shock proteins, which suggests that there exist cooperative 

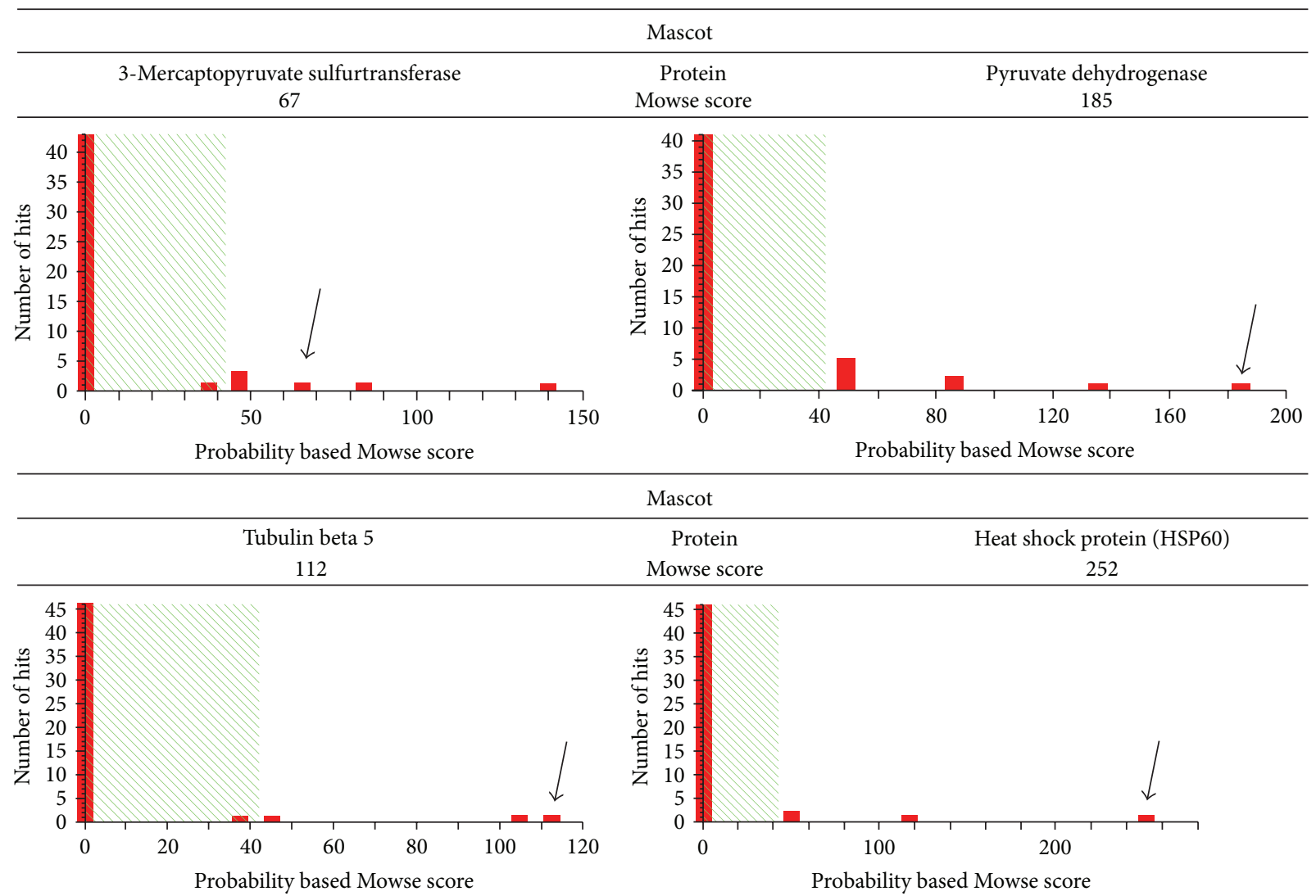

$\begin{array}{cc}\text { Mascot } & \\ \text { Protein } & \text { Heat shock protein (HSP60) } \\ \text { Mowse score } & 252\end{array}$

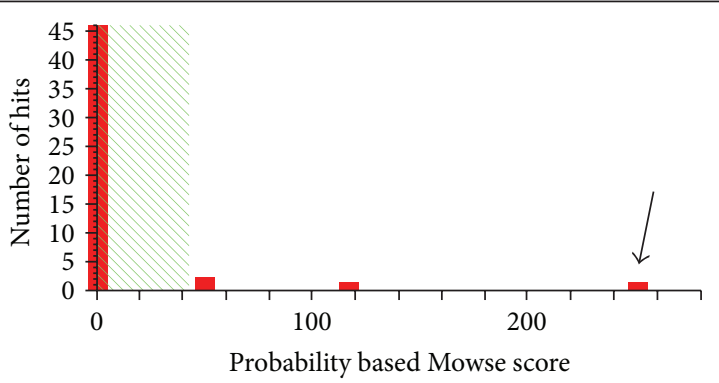

FIGURE 8: Mascot search results for four significantly upregulated proteins in kainic acid-induced apoptosis based on probability based Mowse scores using the Mascot search engine. Possible proteins matched to the spectral masses with differential Mowse scores are shown as multiple bars on the $x$-axis. Only proteins with Mowse scores greater than 64 (outside the shaded area) were considered statistically significantly different $(P<0.05)$. Proteins (without black arrow) were excluded if their masses corresponded to those for trypsin or keratins or to other irrelevant proteins. Black arrows indicate the Mowse score of 3-mercaptopyruvate sulfurtransferase, pyruvate dehydrogenase beta, tubulin beta 5 , and heat shock protein 60 (HSP60).

effects of heat shock proteins in protecting cells from injury and facilitating cell recovery and survival [49]. In our model of KA-induced cortical cell excitotoxicity and apoptosis, these proteins, all of which were antioxidant and antiapoptotic proteins, were significantly activated. The expressions of these proteins suggest the presence of an inducible defense system in apoptotic death that prevents the development of necrosis. Under ER stress conditions, the fate of cells is dependent on the balance between antiapoptotic genes in cell adaptive responses and proapoptotic genes in cell death responses [50]. As a consequence, the balance between the antiapoptotic and proapoptotic effectors or proteins may be critical for determining the cell fate, even in different cell types.

\section{Conclusion}

The functional role of the differentially expressed proteins implies the involvement of apoptosis and not necrosis in excitotoxic brain cortical cell death. Our study demonstrates different protein expression in cells undergoing apoptotic versus necrotic cell death and holds the potential for new treatment strategies for apoptotic death resulting from excitotoxic disease processes. Further research on the complex interactions between these apoptotic proteins as mediators in cell death may validate their role in diseases such as epilepsy.

\section{Conflict of Interests}

The authors declare that there is no conflict of interests regarding the publication of this paper.

\section{Acknowledgments}

This work was supported by a grant from the National Science Council in Taiwan (no. NSC93-2320-B-006-074) and the Top University Plan Outstanding Research Grant. The authors would like to thank the Department of Environmental and Occupational Health, National Cheng Kung University College of Medicine, for LC/MS technical assistance.

\section{References}

[1] M. V. Frantseva, J. L. Perez Velazquez, G. Tsoraklidis et al., "Oxidative stress is involved in seizure-induced neurodegeneration in the kindling model of epilepsy," Neuroscience, vol. 97, no. 3, pp. 431-435, 2000. 
[2] W. S. Kunz, A. P. Kudin, S. Vielhaber et al., "Mitochondrial complex I deficiency in the epileptic focus of patients with temporal lobe epilepsy," Annals of Neurology, vol. 48, no. 5, pp. 766-773, 2000.

[3] L. P. Liang, Y. S. Ho, and M. Patel, "Mitochondrial superoxide production in kainate-induced hippocampal damage," Neuroscience, vol. 101, no. 3, pp. 563-570, 2000.

[4] O. Kann, R. Kovács, M. Njunting et al., "Metabolic dysfunction during neuronal activation in the ex vivo hippocampus from chronic epileptic rats and humans," Brain, vol. 128, no. 10, pp. 2396-2407, 2005.

[5] J. S. Medel-Matus, L. X. Cortijo-Palacios, D. M. Alvarez-Croda, J. Martinez-Quiroz, and M. L. Lopez-Meraz, "Interleukin- $1 \beta$, seizures and neuronal cell death," Revista Peruana de Medicina Experimental y Salud Pública, vol. 30, no. 2, pp. 262-267, 2013.

[6] A.-L. Sokka, N. Putkonen, G. Mudo et al., "Endoplasmic reticulum stress inhibition protects against excitotoxic neuronal injury in the rat brain," The Journal of Neuroscience, vol. 27, no. 4, pp. 901-908, 2007.

[7] S.-W. Jang, M. Okada, I. Sayeed et al., "Gambogic amide, a selective agonist for TrkA receptor that possesses robust neurotrophic activity, prevents neuronal cell death," Proceedings of the National Academy of Sciences of the United States of America, vol. 104, no. 41, pp. 16329-16334, 2007.

[8] S.-T. Kim, S. Jeon, H. J. Park et al., "Acupuncture inhibits kainic acid-induced hippocampal cell death in mice," The Journal of Physiological Sciences, vol. 58, no. 1, pp. 31-38, 2008.

[9] C. Portera-Cailliau, D. L. Price, and L. J. Martin, "Excitotoxic neuronal death in the immature brain is an apoptosis-necrosis morphological continuum," Journal of Comparative Neurology, vol. 378, no. 1, pp. 70-87, 1997.

[10] B. Puig and I. Ferrer, "Caspase-3-associated apoptotic cell death in excitotoxic necrosis of the entorhinal cortex following intraperitoneal injection of kainic acid in the rat," Neuroscience Letters, vol. 321, no. 3, pp. 182-186, 2002.

[11] J. M. Dypbukt, M. Ankarcrona, M. Burkitt et al., "Different prooxidant levels stimulate growth, trigger apoptosis, or produce necrosis of insulin-secreting RINm5F cells: the role of intracellular polyamines," The Journal of Biological Chemistry, vol. 269, no. 48, pp. 30553-30560, 1994.

[12] M. D. Jacobson, J. F. Burne, M. P. King, T. Miyashita, J. C. Reed, and M. C. Raff, "Bcl-2 blocks apoptosis in cells lacking mitochondrial DNA," Nature, vol. 361, no. 6410, pp. 365-369, 1993.

[13] J. Dhein, H. Walczak, C. Baumler, K.-M. Debatin, and P. H. Krammer, "Autocrine T-cell suicide mediated by APO1/(Fas/CD95)," Nature, vol. 373, no. 6513, pp. 438-441, 1995.

[14] L. A. Tartaglia, M. Rothe, Y.-F. Hu, and D. V. Goeddel, “Tumor necrosis factor's cytotoxic activity is signaled by the p55 TNF receptor," Cell, vol. 73, no. 2, pp. 213-216, 1993.

[15] X. R. Yang, P. Sun, H. P. Qin et al., "Involvement of MAPK pathways in NMDA-induced apoptosis of rat cortical neurons," Sheng Li Xue Bao, vol. 64, no. 6, pp. 609-616, 2012.

[16] A. S. Driver, P. R. S. Kodavanti, and W. R. Mundy, "Age-related changes in reactive oxygen species production in rat brain homogenates," Neurotoxicology and Teratology, vol. 22, no. 2, pp. 175-181, 2000.

[17] R. A. P. Harrison, B. Mairet, and N. G. A. Miller, "Flow cytometric studies of bicarbonate-mediated $\mathrm{Ca}^{2+}$ influx in boar sperm populations," Molecular Reproduction and Development, vol. 35, no. 2, pp. 197-208, 1993.
[18] J. S. Armstrong, M. Rajasekaran, W. Chamulitrat, P. Gatti, W. J. Hellstrom, and S. C. Sikka, "Characterization of reactive oxygen species induced effects on human spermatozoa movement and energy metabolism," Free Radical Biology and Medicine, vol. 26, no. 7-8, pp. 869-880, 1999.

[19] E. Miller, "Apoptosis measurement by annexin v staining," Methods in molecular medicine, vol. 88, pp. 191-202, 2004.

[20] T. Eckhardt, "A rapid method for the identification of plasmid desoxyribonucleic acid in bacteria," Plasmid, vol. 1, no. 4, pp. 584-588, 1978.

[21] J. Chang, H. Van Remmen, J. Cornell, A. Richardson, and W. F. Ward, "Comparative proteomics: characterization of a twodimensional gel electrophoresis system to study the effect of aging on mitochondrial proteins," Mechanisms of Ageing and Development, vol. 124, no. 1, pp. 33-41, 2003.

[22] H.-L. Tsai, C.-N. Chang, and S.-J. Chang, "The effects of pilocarpine-induced status epilepticus on oxidative stress/damage in developing animals," Brain and Development, vol. 32, no. 1, pp. 25-31, 2010.

[23] X. Zhu, A. K. Raina, H.-G. Lee, G. Casadesus, M. A. Smith, and G. Perry, "Oxidative stress signalling in Alzheimer's disease," Brain Research, vol. 1000, no. 1-2, pp. 32-39, 2004.

[24] J. B. Schulz, D. R. Henshaw, D. Siwek et al., "Involvement of free radicals in excitotoxicity in vivo," Journal of Neurochemistry, vol. 64, no. 5, pp. 2239-2247, 1995.

[25] D.-H. Hyun, M. Lee, N. Hattori et al., "Effect of wild-type or mutant parkin on oxidative damage, nitric oxide, antioxidant defenses, and the proteasome," The Journal of Biological Chemistry, vol. 277, no. 32, pp. 28572-28577, 2002.

[26] Y. H. Shih, S. L. Wu, W. F. Chiou, H. H. Ku, T. L. Ko, and Y. S. Fu, "Protective effects of tetramethylpyrazine on kainate induced excitotoxicity in hippocampal culture," NeuroReport, vol. 13, no. 4, pp. 515-519, 2002.

[27] V. P. Skulachev, "Mitochondria in the programmed death phenomena; a principle of biology: "it is better to die than to be wrong'”' IUBMB Life, vol. 49, no. 5, pp. 365-373, 2000.

[28] A. F. Schinder, E. C. Olson, N. C. Spitzer, and M. Montal, "Mitochondrial dysfunction is a primary event in glutamate neurotoxicity," The Journal of Neuroscience, vol. 16, no. 19, pp. 6125-6133, 1996.

[29] R. J. White and I. J. Reynolds, "Mitochondrial depolarization in glutamate-stimulated neurons: an early signal specific to excitotoxin exposure," The Journal of Neuroscience, vol. 16, no. 18, pp. 5688-5697, 1996.

[30] F. X. Sureda, C. Gabriel, J. Comas et al., "Evaluation of free radical production, mitochondrial membrane potential and cytoplasmic calcium in mammalian neurons by flow cytometry," Brain Research Protocols, vol. 4, no. 3, pp. 280-287, 1999.

[31] L. Formigli, L. Papucci, A. Tani et al., "Aponecrosis: morphological and biochemical exploration of a syncretic process of cell death sharing apoptosis and necrosis," Journal of Cellular Physiology, vol. 182, no. 1, pp. 41-49, 2000.

[32] T. N. Parks, L. D. Artman, N. Alasti, and E. F. Nemeth, "Modulation of $N$-methyl-D-aspartate receptor-mediated increases in cytosolic calcium in cultured rat cerebellar granule cells," Brain Research, vol. 552, no. 1, pp. 13-22, 1991.

[33] D.-H. Youn and M. Randić, "Modulation of excitatory synaptic transmission in the spinal substantia gelatinosa of mice deficient in the kainate receptor GluR5 and/or GluR6 subunit," The Journal of Physiology, vol. 555, no. 3, pp. 683-698, 2004.

[34] M. Tymianski, "Cytosolic calcium concentrations and cell death in vitro," Advances in Neurology, vol. 71, pp. 85-105, 1996. 
[35] F. J. Martín-Romero, J. R. Ortíz-de-Galisteo, J. Lara-Laranjeira, J. A. Domínguez-Arroyo, E. González-Carrera, and I. S. Álvarez, "Store-operated calcium entry in human oocytes and sensitivity to oxidative stress," Biology of Reproduction, vol. 78, no. 2, pp. 307-315, 2008.

[36] A. H. Wyllie, "Apoptosis: cell death under homeostatic control," Archives of Toxicology, vol. 60, no. 11, pp. 3-10, 1987.

[37] T. Engel, S. Hatazaki, K. Tanaka, J. H. M. Prehn, and D. C. Henshall, "Deletion of puma protects hippocampal neurons in a model of severe status epilepticus," Neuroscience, vol. 168, no. 2, pp. 443-450, 2010.

[38] F. Pellegrini and D. R. Budman, "Review: tubulin function, action of antitubulin drugs, and new drug development," Cancer Investigation, vol. 23, no. 3, pp. 264-273, 2005.

[39] A. Jordan, J. A. Hadfield, N. J. Lawrence, and A. T. McGown, "Tubulin as a target for anticancer drugs: agents which interact with the mitotic spindle," Medicinal Research Reviews, vol. 18, no. 4, pp. 259-296, 1998.

[40] C. Gerner, U. Fröhwein, J. Gotzmann et al., "The Fas-induced apoptosis analyzed by high throughput proteome analysis," The Journal of Biological Chemistry, vol. 275, no. 50, pp. 3901839026, 2000.

[41] B. H. Robinson, H. MacMillan, R. Petrova-Benedict, and W. G. Sherwood, "Variable clinical presentation in patients with defective $\mathrm{E}_{1}$ component of pyruvate dehydrogenase complex," The Journal of Pediatrics, vol. 111, no. 4, pp. 525-533, 1987.

[42] C. G. Concannon, L. P. Tuffy, P. Weisová et al., "AMP kinasemediated activation of the $\mathrm{BH} 3$-only protein Bim couples energy depletion to stressinduced apoptosis," The Journal of Cell Biology, vol. 189, no. 1, pp. 83-94, 2010.

[43] E. N. Churchill, C. L. Murriel, C. H. Chen, D. Mochly-Rosen, and L. I. Szweda, "Reperfusion-induced translocation of $\delta$ PKC to cardiac mitochondria prevents pyruvate dehydrogenase reactivation," Circulation Research, vol. 97, no. 1, pp. 78-85, 2005.

[44] J. Terrand, I. Papageorgiou, N. Rosenblatt-Velin, and R. Lerch, "Calcium-mediated activation of pyruvate dehydrogenase in severely injured postischemic myocardium," American Journal of Physiology - Heart and Circulatory Physiology, vol. 281, no. 2, pp. H722-H730, 2001.

[45] N. Nagahara and A. Katayama, "Post-translational regulation of mercaptopyruvate sulfurtransferase via a low redox potential cysteine-sulfenate in the maintenance of redox homeostasis," The Journal of Biological Chemistry, vol. 280, no. 41, pp. 3456934576, 2005.

[46] J.-S. Bian, C. Y. Qian, T.-T. Pan et al., "Role of hydrogen sulfide in the cardioprotection caused by ischemic preconditioning in the rat heart and cardiac myocytes," Journal of Pharmacology and Experimental Therapeutics, vol. 316, no. 2, pp. 670-678, 2006.

[47] S. K. Kim, K. C. Wang, S. J. Hong et al., "Gene expression profile analyses of cortical dysplasia by cDNA arrays," Epilepsy Research, vol. 56, no. 2-3, pp. 175-183, 2003.

[48] S. R. Kirchhoff, S. Gupta, and A. A. Knowlton, "Cytosolic heat shock protein 60, apoptosis, and myocardial injury," Circulation, vol. 105, no. 24, pp. 2899-2904, 2002.

[49] J. Demand, S. Alberti, C. Patterson, and J. Höhfeld, "Cooperation of a ubiquitin domain protein and an E3 ubiquitin ligase during chaperone/proteasome coupling," Current Biology, vol. 11, no. 20, pp. 1569-1577, 2001.

[50] P. Hu, Z. Han, A. D. Couvillon, and J. H. Exton, "Critical role of endogenous Akt/IAPs and MEK1/ERK pathways in counteracting endoplasmic reticulum stress-induced cell death,"
The Journal of Biological Chemistry, vol. 279, no. 47, pp. 49420 49429, 2004. 

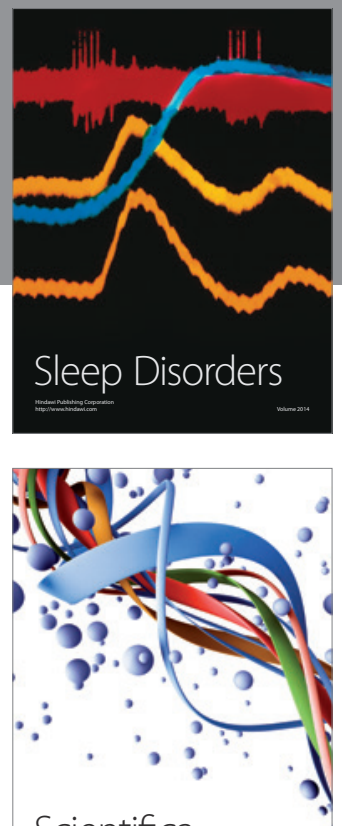

Scientifica
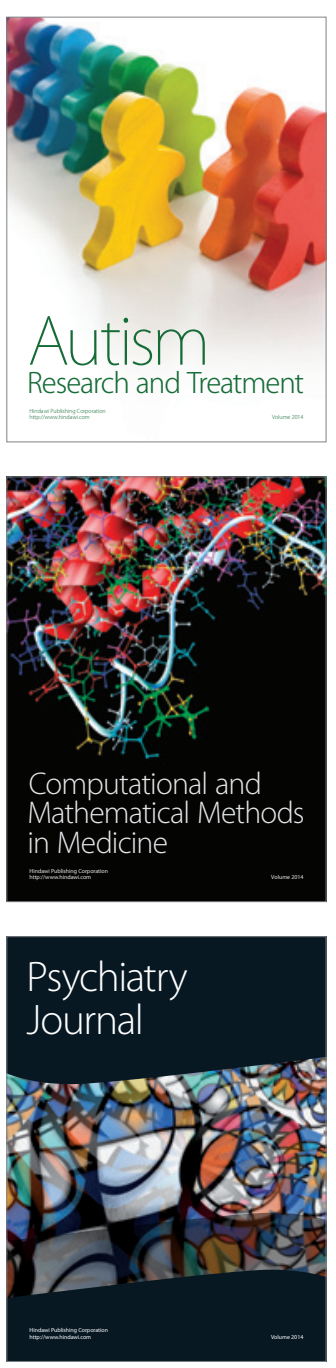
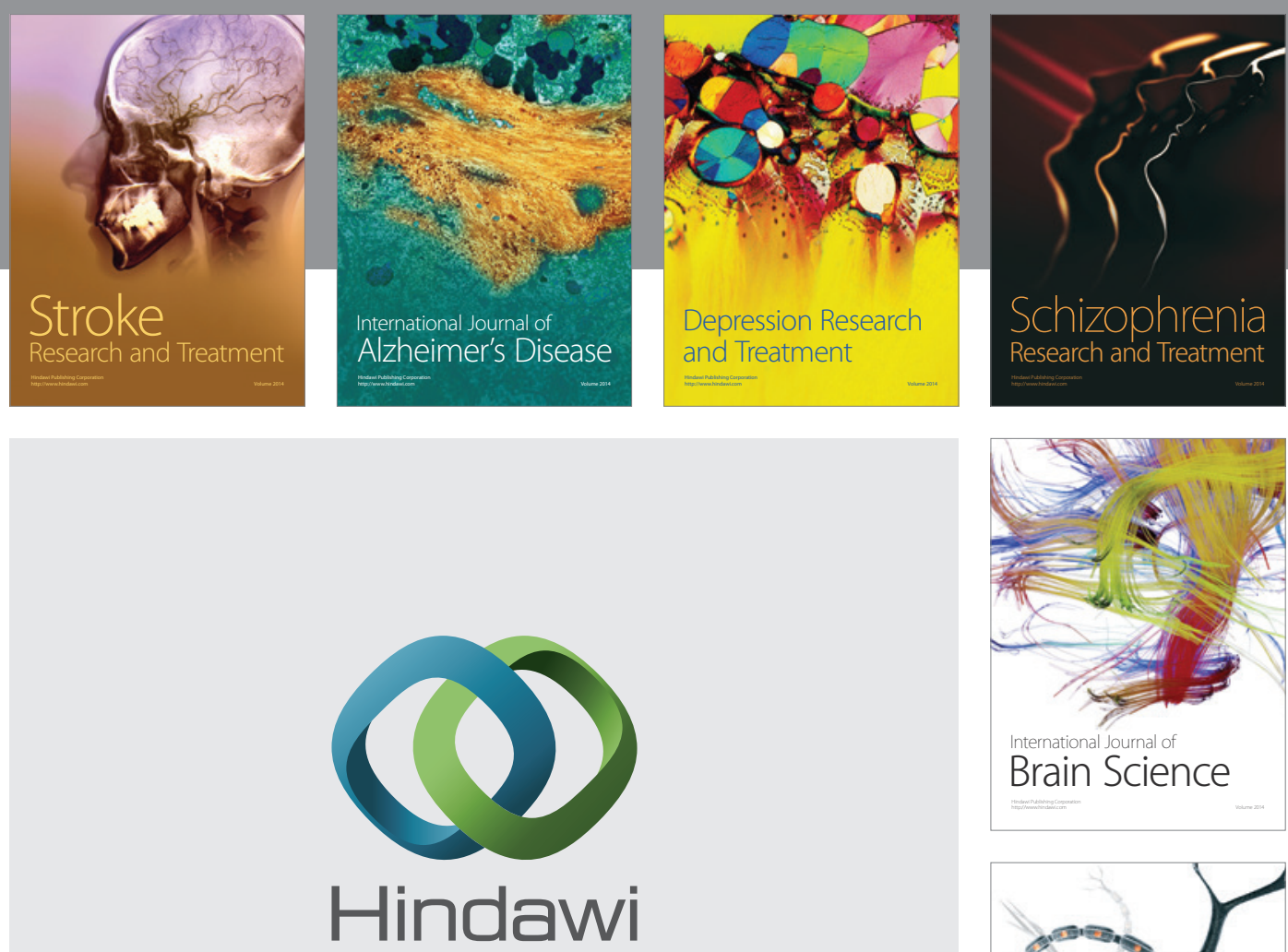

Submit your manuscripts at

http://www.hindawi.com
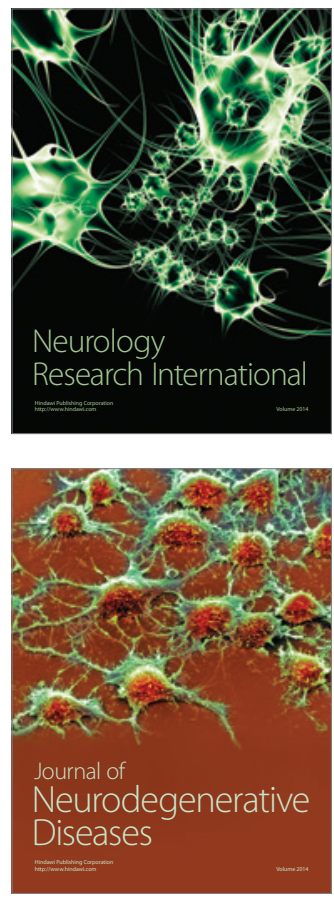

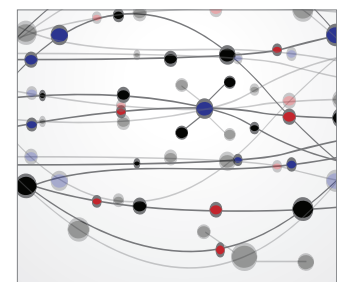

The Scientific World Journal
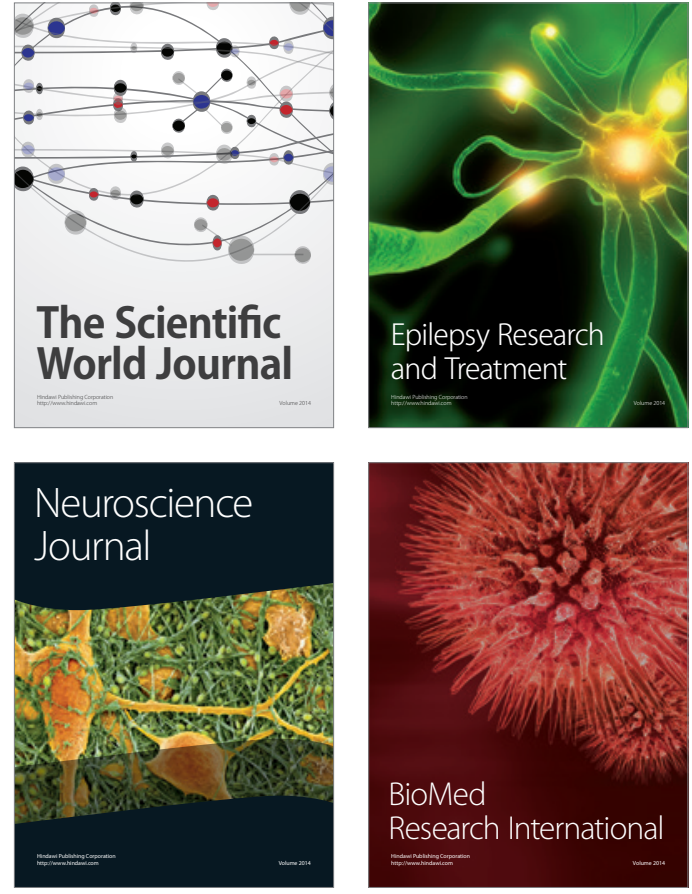

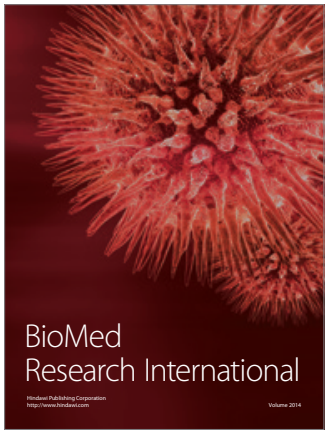

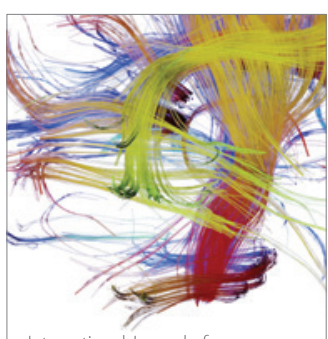

Brain Science

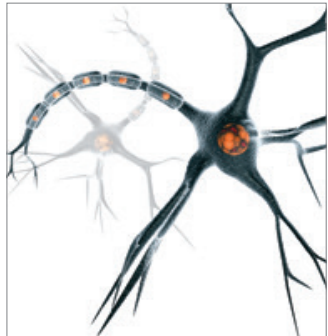

Neural Plasticity
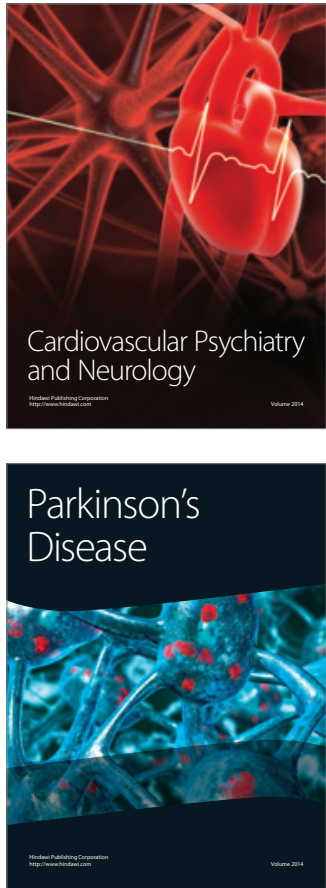